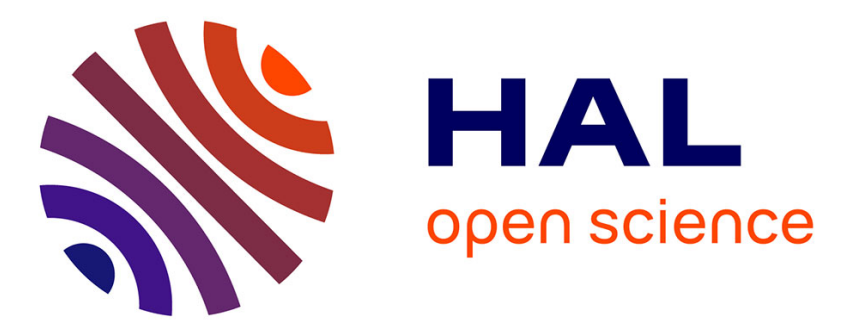

\title{
The Tragedy of Corruption Corruption as a social dilemma
}

Ye-Feng Chen, Shu-Guang Jiang, Marie Claire Villeval

\section{To cite this version:}

Ye-Feng Chen, Shu-Guang Jiang, Marie Claire Villeval. The Tragedy of Corruption Corruption as a social dilemma. 2015. halshs-01236660v2

\section{HAL Id: halshs-01236660 \\ https://shs.hal.science/halshs-01236660v2}

Preprint submitted on 31 Aug 2016

HAL is a multi-disciplinary open access archive for the deposit and dissemination of scientific research documents, whether they are published or not. The documents may come from teaching and research institutions in France or abroad, or from public or private research centers.
L'archive ouverte pluridisciplinaire HAL, est destinée au dépôt et à la diffusion de documents scientifiques de niveau recherche, publiés ou non, émanant des établissements d'enseignement et de recherche français ou étrangers, des laboratoires publics ou privés. 
UMR 5824

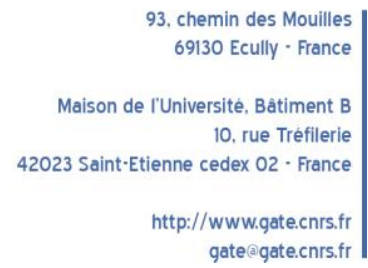

WP 1531 - December 2015, revised August 2016

\title{
The Tragedy of Corruption Corruption as a social dilemma
}

\author{
Ye-Feng Chen, Shu-Guang Jiang, Marie Claire Villeval
}

\begin{abstract}
:
We investigate corruption as a social dilemma by means of a bribery game in which a risk of collective failure is introduced when the number of public officials accepting a bribe from firms reaches a certain threshold. We show that, despite the social risk, the pursuit of individual interest prevails and leads to the elimination of honest officials over time. Reducing the size of the groups while increasing the probability of collective failure diminishes the public officials' corruptibility but is not sufficient to eliminate the tragedy of corruption altogether.
\end{abstract}

\section{Keywords:}

Corruption, bribing, social dilemma, collective failure, coordination, experiment.

JEL codes:

C92, D73, H41

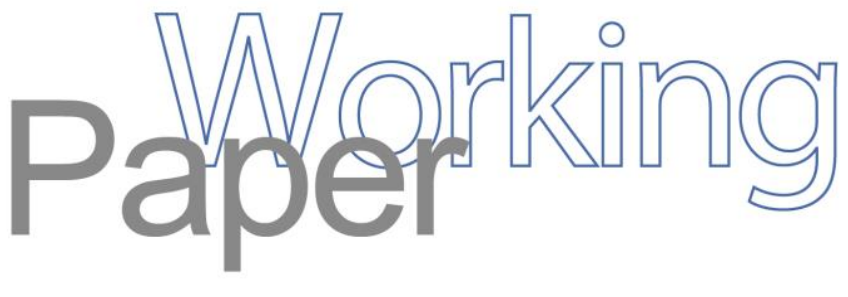




\title{
The Tragedy of Corruption
}

\author{
Yefeng Chen $^{\mathrm{a}}$, Shuguang Jiang ${ }^{\mathrm{b}, \mathrm{c}}$, Marie Claire Villeval ${ }^{\mathrm{de,}, \mathrm{f}}$
}

This version: August 22, 2016

\begin{abstract}
We investigate corruption as a social dilemma by means of a bribery game in which a risk of collective sanction of the public officials is introduced when the number of officials accepting a bribe from firms reaches a certain threshold. We show that, despite the social risk, the pursuit of individual interest prevails and leads to the elimination of honest officials over time. Reducing the size of the groups while increasing the probability of collective sanction diminishes the officials' corruptibility but is not sufficient to eliminate the Tragedy of corruption that leads both firms and officials to earn less than in the absence of corruption.
\end{abstract}

Keywords: Corruption, social dilemma, collective risk, sanction, experiment

JEL Codes: C92, D73, H41

${ }^{a}$ College of Economics, Zhejiang University, China. lenggone@gmail.com.

${ }^{\mathrm{b}}$ College of Economics, Zhejiang University, China

${ }^{c}$ Centre for Economic Research, Shandong University, China.jsg123000@sina.com.

${ }^{\mathrm{d}}$ Univ Lyon, CNRS, GATE, 93 Chemin des Mouilles, F-69130, Ecully, France. villeval@gate.cnrs.fr

${ }^{\mathrm{e}}$ IZA, Bonn, Germany

${ }^{\mathrm{f}}$ Department of Public Finance, University of Innsbruck

* This research has been supported by a grant of the French National Research Agency (ANR, FELIS grant, ANR-14CE28-0010-01). It was performed within the framework of the LABEX CORTEX (ANR-11-LABX-0042) of Université de Lyon, within the program Investissements d'Avenir (ANR-11-IDEX-007) operated by Agence Nationale de la Recherche. 


\section{Introduction}

Running a government efficiently requires the cooperation of public officials who are loyal to their duties and enforce laws impartially. However, the corruption of public officials is a widespread phenomenon in many countries all over the world (Transparency International, 2016). The World Bank Institute has estimated in 2005 that more than US\$1 trillion are paid in bribes each year, which represents about $2 \%$ of global GDP, with dramatic consequences on development (Shleifer and Vishny, 1993; Mauro, 1995) and poverty (Alesina and Angeletos, 2005). Although even in corrupt countries public officials may agree that integrity is best to everyone, the high return of corruption can induce individuals who have some discretion on public affairs to betray the public interest.

Accepting a bribe in exchange of a favor may be rational from a strictly selfish individual point of view although this behavior may harm the group of officials as a whole. Indeed, individual and collective interests are at odds when bribe offers introduce an incentive to free ride, i.e. to maximize one's individual payoff instead of contributing to safeguard the reputation of the government or instead of protecting the whole group of public officials against a risk of collective sanction. The damage to reputation from widespread corruption may cause a crisis of confidence in the government and even trigger its crash in the most severe cases. ${ }^{1}$ Evidence shows that it also occurs to political parties, companies, and organizations, harming all their members, including those who are not corrupt. ${ }^{2}$ Widespread corruption may also lead to massive crackdown policies that may entail collective sanctions and a collective loss of reputation regardless of individual

\footnotetext{
1 Throughout history, corruption has played a decisive role in the rise and fall of states and organizations. For example, the "Dynasty Periodic Law" in ancient China characterizes the replacement of ruling dynasties every few hundred years; it is widely believed to be related to the growing and excessive corruption of the ruling class which, inevitably diminishes the dynasty's political power (Wang, 2002). Other famous examples of the failures of governments due to widespread corruption in the bureaucratic system can be found in the decline of the Roman Empire (MacMullen, 1988), or, more recently, the Color Revolution in the former Soviet republics. Treisman (2000) has also shown that a longer exposure to democracy is associated with a lower degree of corruption in a country.

2 The Enron Corporation and Volkswagen scandals are examples of organizational failure due to corporate fraud and corruption by a small fraction of the employees but which consequences have harmed all the employees. In the domain of sports, the World Anti-Doping Agency commission has threatened to ban Russia from the 2016 Olympics because of the massive doping and corruption of a fraction of the Russian athletes.
} 
behavior (e.g., the "Tiger and Flies" crackdown conducted against corruption in China; see also Di Tella and Schargrodsky, 2003; Banuri and Eckel, 2015). This suggests that corruption could be studied as a social dilemma.

The main aim of this paper is thus to analyze corruption in terms of social dilemma and to investigate how the risk of collective sanctions affects individuals' corruptibility. The novelty of our contribution is complementing the traditional approach of corruption inspired by Becker and Stigler (1974) and Rose-Ackerman (1975) that relies on a cost-benefit analysis and on the agency theory. The principal-agent model of corruption rests on the assumption that the principal takes on the role of controlling corruption (Rauch and Evans, 2000). However, as argued by Persson et al. (2013), this model cannot capture all the fundamental aspects of corruption. In particular, corrupt behavior does not depend solely on a cost-benefit analysis, and it does not dissolve in the vertical relationship between an agent and a principal. Approaching corruption as a social dilemma allows us to account for the horizontal interdependencies among corruptible individuals. Everyone has the incentive to free-ride by accepting bribes due to the lure of private benefit, but everyone is also exposed as a victim of others' corruption. This perspective gives a fundamental motivation for behavior -the overall interest of the group- that was largely underexplored by previous studies on corruption (see surveys by Aidt, 2003, and Abbink and Serra, 2012).

In this paper, we investigate corruption as a public bad in a stochastic environment, by designing a laboratory experiment based on the sequential bribery game of Abbink et al. (2002). Specifically, each firm in a group is paired with a public official and they repeatedly interact with each other in a partner-matching relationship. The firm can offer a bribe to the official for obtaining the permission to develop a project. The official has to decide whether or not to accept the bribe, and, then, whether or not to grant permission to the firm. Granting permission increases the payoff of the firm, but harms every other firm, creating a negative externality. We depart from Abbink et al. (2002) in that, in each period of the game, if the percentage of officials who accept a 
bribe exceeds a certain threshold, this triggers a risk of collective sanction of the group of officials, which constitutes a second negative externality. The collective sanction means that all the officials in the group lose most of their payoffs in the period, regardless of whether they are corrupt or not. ${ }^{3}$ This corresponds to a setting in which it is impossible to detect corruption at the individual level because information is hardly accessible, but in which there is sufficient evidence of a high corruption level in the group to trigger a collective but non definitive sanction. This endogenous collective sanction mechanism replaces the exogenous "sudden death" mechanism in Abbink et al. (2002) that is defined as an extremely low probability event $(p=0.003)$ which lets a pair of corrupt players lose all their payoffs and be excluded from the game. In contrast in our game, firms are not sanctioned for bribing because our mechanism does not require the identification of corruption at the individual level and we are chiefly interested in the dynamics of coordination among the officials. Only the officials are sanctioned but they are sanctioned as a group and for one period. Thus, our mechanism turns the initial principal-agent game into a social dilemma game. It captures the tension of the officials between pursuing their individual interest (accepting a bribe) and serving the collective interest of the group (resisting the temptation, so as to maintain the integrity of their own and their group payoffs). This design allows us to study whether players are able to cooperate to avoid collective sanctions.

In this framework, we extend the initial game of Jiang and Chen (2016) by investigating the impact of two variables on the intensity of corruption: the probability of a collective sanction of the officials and the group size. Indeed, different environments can generate different probabilities of sanction in case of widespread corruption. In real settings, these differences can result from various tolerance norms or from the implementation of more or less deterrent policies (e.g., massive crackdowns on corruption increase the probability of sanction). When the risk of

\footnotetext{
3 This parallels the rule in public goods game according to which individuals benefit from the public goods regardless of their individual contribution.
} 
collective sanction is high, the members of a group must cooperate more effectively to avoid it. In contrast, in a low risk environment, individuals may be more likely to follow their selfish interests. The second variable of importance is the size of the group. Indeed, as surveyed in Section 2, previous literature has shown that the group size may impact cooperation through its effect on the production technology in public goods games, but no consensus has been found on the direction of its effect. In the context of corruption, when the group size is relatively small, we anticipate that an official can feel a stronger sense of responsibility for the punishment of his group because of his higher probability to be the key player whose decision triggers the risk of sanction. Moreover, it may be easier to coordinate with the other officials to avoid reaching the critical threshold. On the other hand, if a sanction occurs in a small group, it will affect a lower number of officials than in a large group, and this may weaken the sense of responsibility. It is therefore interesting to investigate which effect dominates. We use a $2 \times 2$ experimental design to test the impact of the risk of collective sanction and of the group size on corruption. The probability of a collective sanction is either $20 \%$ or $60 \%$, and the size of a group is either 10 or 20 members. ${ }^{4}$

Our main findings are as follows. Overall, we observe a high level of corruption: the percentage of firms offering a bribe is $72 \%$; the percentage of officials accepting a bribe is $81 \%$, and the social corruption rate, defined as the percentage of officials who receive a bribe, accept it and then grant the permission, ${ }^{5}$ is $41 \%$. The lowest social corruption level $(31.22 \%)$ is observed in small groups under high risk of sanction, while the highest level $(47.11 \%)$ is found in large groups under low risk. The likelihoods of accepting a bribe and of granting the permission to a firm both decrease when the risk of sanction is higher, while the group size matters mainly under a high risk of sanction. The officials' corruptibility also depends positively on their beliefs about others' behavior and their justification of corruption, while it depends negatively on their pro-social

\footnotetext{
4 Jiang and Chen (2016) only consider groups of 20 players and a risk of collective sanction of $60 \%$.

5 This rate defines social corruption in the sense that it reflects the behavior of both firms and officials.
} 
orientation. Despite the risk of collective sanction, the dynamics of corruption leads to the progressive elimination of honest officials. This parallels the decay of cooperation in public goods games. In contrast, there is limited evidence of an influence of the group size and of the risk of collective sanction of officials on the firms' decision to bribe, probably because firms are not targeted by the sanction mechanism. However, conditional on attempting to bribe, firms offer higher bribes in small groups when the risk of sanction is high than in large groups under low risk.

Another major result is providing evidence of the "Tragedy of corruption", by analogy with the Tragedy of commons in environmental social dilemmas. Indeed, both firms and officials are harmed by corruption, as their mean payoffs are lower than the payoffs received in the absence of corruption. The lower payoff of firms results from the negative externalities generated by permissions granted by corrupt officials. The lower payoff of officials originates in the negative externalities generated by their selfish behavior and their inability to coordinate to avoid their collective punishment. This novel result suggests a number of directions for further research.

The remainder of this paper is organized as follows: Section 2 reviews briefly the literature; Section 3 describes the experimental design and procedures, and presents our behavioral conjectures; Section 4 reports our results and Section 5 discusses and concludes.

\section{Related literature}

The traditional approach of corruption is grounded in the principal-agent model (Rose-Ackerman, 1999; Jain, 2001). In this framework, the government is the principal and the public official is the agent (Becker and Stigler, 1974; Van Rijckeghem and Weder, 2001). Experimental studies have shown that the agents' willingness to engage in corruption is affected by the level of wages (Abbink, 2005; Armantier and Boly, 2011; van Veldhuizen, 2013), the monitoring capacity (Azfar and Nelson, 2007; Olken, 2007; Barr et al., 2009; Serra, 2012), the risk of penalty (Abbink et al., 2002), staff rotation (Abbink, 2004), asymmetric liability (Abbink et al., 2014), or information (Berninghaus et al., 2013; di Falco et al., 2016). Generally, it has been found that officials with 
higher wages, subject to rigorous monitoring and severe punishment when corruption is detected are less corrupt (see Abbink and Serra, 2012, for a review). Moreover, variations in the structure of governments and in the electoral systems contribute to explain the differences in corruption practices across countries (Shleifer and Vishny, 1993; Persson and Tabellini, 2004; Ferraz and Finan, 2011). ${ }^{6}$ Our study differs in that instead of analyzing corruption as a principal-agent problem, we analyze it as a social dilemma problem, i.e., we let the collective interests of public officials conflict with their individual interests. ${ }^{7}$

We investigate the impact of group size on corruption. Alesina and Angeletos (2005) have shown that bigger governments increase the gains from corruption because they control a larger share of the resources. Here, we investigate another reason for which the group size can affect the level of corruption: its impact on free-riding. The literature on social dilemmas has generally found that cooperation declines as the group size increases (see Sally, 1995, and Zelmer, 2003, for surveys and Olson, 1965; Hamburger et al., 1975; Boyd and Richerson, 1988; Van Huyck et al., 1990; Santos and Pacheco, 2011). However, Isaac and Walker (1988) and Isaac et al. (1994) have shown that contributions in public goods games may increase in large groups because the social benefit of contributing increases in the group size, but they identified no difference between groups of 40 or 100 subjects. Weimann et al. (2012) also found no effect of larger group size (groups of 60 vs. 100 players) on contributions for a given marginal per capita return (MPCR), and they have shown that contributions depend on the interaction between the group size and the MPCR. Recently, Nosenzo et al. (2015) have found that cooperation increases with size when the MPCR is low, and vice-versa. In contrast, our contribution is to analyze the effect of group size on collective action in a public bad situation under different risks of collective sanction.

\footnotetext{
${ }^{6}$ For empirical investigations on the determinants of corruption at the cross-country level, see Svensson (2005), Lambsdorff (2006), Serra (2006), Treisman (2000, 2007), Dimant and Schulte (2016) for reviews.

7 Abbink et al. (2002) include a public bad dimension in a treatment where granting permission leads to negative externalities on all players. However, accepting a bribe in itself does not harm the other players.
} 
We investigate the impact of the probability of collective sanction of officials on corruption. By considering the punishment of the whole group in a stochastic environment, we differ from most of the literature on sanctions in social dilemmas that considers the punishment of individual violators, either based on peer punishment (e.g., Fehr and Gächter, 2000) or on centralized mechanisms (e.g., Putterman et al., 2011). We are closer to Fatas et al. (2010) who consider a blind punishment mechanism according to which the probability of a sanction depends on the performance of the whole group in a team production game. But in their study the punishment is randomly assigned to an individual group member, which again differs from our collective approach. In contrast, the recent collective-risk social dilemma games (e.g. Milinski et al., 2008; Santos and Pacheco, 2011; Tavoni et al., 2011; Chen and Perc, 2014) capture situations in which agents need to coordinate to prevent an undesirable event that affects all of them. The collective risk is usually introduced in threshold public goods: if contributions do not reach the threshold, then a collective damage may occur (e.g., Dannenberg et al., 2015). It is found that a higher risk increases the chances of coordinating actions. Santos and Pacheco (2011) show that the combination of a smaller group size and a higher risk increases the capability to solve the social dilemma. Our experiment also uses a collective-risk social dilemma game, but it differs from previous studies by considering a threshold public bad. While in threshold public goods games subjects have to cooperate to reach the provision threshold, in our study they have to cooperate to avoid reaching the threshold that triggers the sanction. ${ }^{8}$

\footnotetext{
${ }^{8}$ Note that although we elicit the players' beliefs only indirectly at the end of the game, our study does not ignore the role of beliefs on group norms. The studies on cooperation give consistent evidence that whatever action ought to be taken depends on shared expectations about how others will act (Ostrom, 1998; Gintis et al., 2005). Public goods experiments like Gächter and Herrmann (2009) and Fischbacher and Gächter (2010), have stressed that, for a majority of subjects, cooperation is conditional on the beliefs about others' contributions. For their part, studies on dishonesty have found that individuals' compliance behavior is influenced by the norm prevailing in the group (see Balafoutas, 2011, and Dong et al., 2012, on the role of beliefs on corruption). Our originality is studying the net outcome of two opposite effects, as, on the one hand, beliefs of a high corruption level in the group may relax the norm of honesty but, on the other hand, they may increase the subjective risk of collective sanction.
} 


\section{Experimental design, predictions, and procedures}

We first present our experimental design, starting with a definition of the game used in the baseline condition before introducing the treatments. Secondly, we develop behavioral predictions. Finally, we detail the procedures.

\subsection{Experimental design}

\section{The game}

Our game builds on the sequential bribery game developed by Abbink et al. (2002). It involves two types of players: firms who can offer a bribe to public officials in exchange for a favor, and public officials who can accept or reject the bribe and grant or deny the favor. We retain two essential characteristics of the initial game: the reciprocity relationship between bribers and officials, and the negative externality of bribery on other players. In contrast to Abbink et al. (2002), our game does not involve a centralized exogenous punishment mechanism of pairs of bribers and bribees, but introduces instead a risk of collective sanction for the public officials, as described below. This new design turns the initial principal-agent game into a social dilemma game. Let us describe this game.

A group consists of firms and public officials in equal number. Each firm is matched with an official, and they interact repeatedly during 30 periods in a fixed partner matching protocol. In each period, the firm is willing to run a project that increases its profit but harms the other firms. The public official must decide whether or not to grant permission to the firm to run the project. Several firms can run their project if different officials grant permission.

The game has three stages. In the first stage, the firm decides on whether or not to offer a bribe to the official. If it offers a bribe, it has to decide on the amount of the bribe, from 1 to 9 points. Bribing the official entails a fixed cost of 1 point (this fee could represent the time spent approaching the official, for example). In the second stage, the official who is offered a bribe has to decide to accept or reject it. If he rejects the bribe, the payoffs of both the firm and the official 
remain unchanged, except that the fixed bribing cost is deducted from the firm's account. If the official accepts the bribe, then the amount offered is deducted from the firm's account, and the official's account is increased by the tripled amount of the bribe. ${ }^{9}$ In the third stage, the official has to decide whether or not to grant permission to the firm to run its project. If he denies permission, both the firm and the official earn 36 points. If he grants permission, the firm earns 56 and the official earns 33. The cost for the official to grant permission may represent, for example, his effort to justify his decision. Granting permission causes a negative externality on each of the other firms: each one suffers a 2 points loss each time an official grants permission to a firm.

However, in each period, if the percentage of corrupt officials (i.e. those who accepted a bribe, regardless of whether or not this led them to grant permission) in the group exceeds $60 \%$, the whole group of officials faces a risk of collective sanction. ${ }^{10}$ When a collective sanction occurs, all the officials, corrupt or not, lose $80 \%$ of their payoff in the period but there is no direct consequence on the firms. As already explained, this introduces two major differences with the initial game of Abbink et al. (2002): on the one hand, the mechanism does not require the identification of bribery at the pair level, but on the other hand it cannot affect the briber -the firm- directly. ${ }^{11}$ This mechanism introduces a social dilemma: accepting a bribe increases the official's payoff, but meanwhile, it raises the social risk of sanction.

Figure 1 illustrates the decision process. " $t$ " denotes the amount of the bribe proposed by a firm. In each terminal node, the first line represents the payoff of the firm, and the second line the official's payoff when no sanction occurs (with his payoff in case of a sanction in parentheses). On the third line, $(-2, \ldots,-2)$ represents the negative consequence of granting permission on each of

\footnotetext{
9 Abbink et al. (2002) argue that this factor reflects a difference in marginal utility: in the real world, the same amount of money means less to the briber than to the public official.

${ }^{10}$ In the instructions, we used the notion of « collective failure » instead of « collective sanction »; indeed, the notion of coordination failure is less loaded than that of sanction or punishment.

11 Another difference between our game and Abbink et al. (2002) is that the negative externality generated by the permissions harms only the firms in our game, and not all the players. The reason is that we wanted to separate the negative impact of corruption on firms due to the permissions to run the project, from its negative impact on officials due to the risk of collective sanction.
} 
the other firms' payoff. Note that the figure is incomplete since it only displays the two-player moves, while the final payoffs also depend on the decisions of all other pairs in the group.

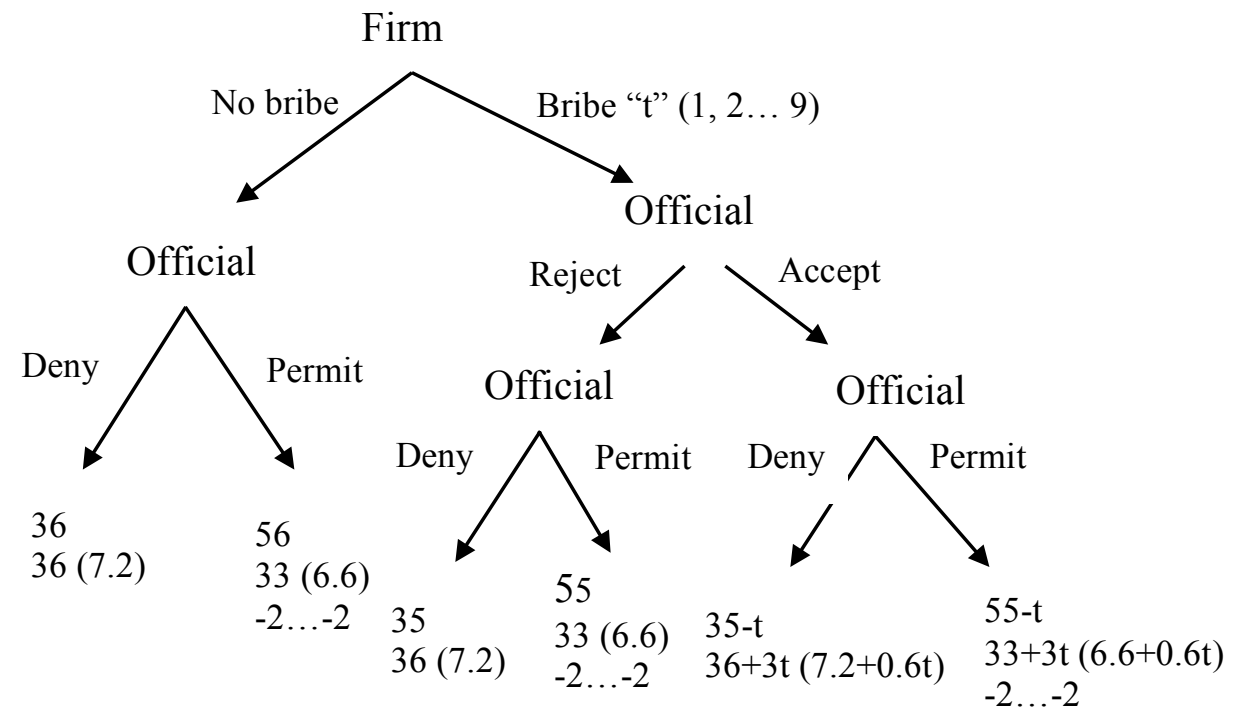

Figure 1 . The bribery game

At the end of each period, each subject receives a feedback indicating the decision of his partner and his own payoff for the period. In addition, officials (not firms) learn whether a sanction occurred or not. No player is informed on the number of bribes offered and accepted. Firms (not officials) can indirectly learn the number of permissions granted in their group through their payoff reduction. Subjects are paid the sum of their payoffs in each period.

Since the bribery game involves a risk of collective sanction, we elicited the subjects' risk preferences, using the Eckel and Grossman's (2008) procedure. ${ }^{12}$ This elicitation took place at the beginning of each session, but no feedback was ever given to the subjects before the very end of the session. In case of a loss, the loss was deducted from the earnings from the main game.

\footnotetext{
12 Subjects were asked to choose which of six gambles to play. Each lottery offers a $50 \%$ probability of winning a higher payoff. The payoff of the six gambles are: $(50,50),(90,30),(130,10),(170,-10),(210,-30),(220,-40)$. The expected payoff increases from one lottery to the next, as well as its standard deviation. The last two lotteries have the same expected payoff but the last one is more risky.
} 


\section{Treatments}

A $2 \times 2$ factorial design involves four treatments that are implemented in a between-subject design. Treatments vary in the group size and in the probability of collective sanction. The group size is either large (20 subjects) or small (10 subjects); the risk is either high $(60 \%)$ or low $(20 \%)$.

In the Large group - Low risk treatment (LL, hereinafter), there are 20 participants in a group (10 firms and 10 officials). When the percentage of officials who accept a bribe exceeds the threshold of $60 \%$ ( 6 corrupt officials), there is a $20 \%$ probability that a collective sanction occurs. In the Large group - High risk treatment ( $\mathrm{LH}$, hereinafter), the group size is also 20, but the probability of a collective sanction is $60 \%$. In the Small group - Low risk treatment (SL, hereinafter), there are 10 participants in a group ( 5 firms and 5 officials). When the percentage of officials who accept a bribe exceeds the threshold of $60 \%$ (3 corrupt officials), a collective sanction occurs with a $20 \%$ probability. In the Small group - High risk treatment (SH, hereinafter), the group size is also 10 , but the probability of a collective sanction is $60 \%$.

\subsection{Theoretical Predictions}

\section{Standard predictions}

In equilibrium, with standard preferences, firm do not offer bribes and officials do not grant permissions. Indeed, in a period, regardless of the firm's decision, the official will not grant permission since this would reduce his payoff (from 36 to 33). Therefore, in any finitely repeated situation, it cannot be an equilibrium strategy for the firm to bribe the official. This prediction holds true, regardless of the group size and the probability of collective sanction. The bribery relationship is not an enforceable contract. This leads to our first conjecture:

Conjecture 1 (Standard preferences): Corruption is not an equilibrium strategy.

\section{Behavioral predictions}

Alternatively, as argued notably by Abbink et al. (2002) and Abbink and Hennig-Schmidt (2006), the bribery relationship can occur if players have social preferences and express trust and 
reciprocity. Indeed, a trustful firm may try to bribe the official. When a single official is not the key player who triggers the risk of collective sanction, his optimal choice is accepting the bribe. If reciprocal, he will grant permission to the firm. When an official is the key player, he is indifferent between accepting the bribe and granting permission, on the one hand, and rejecting the bribe and denying permission, on the other hand, when the bribe amount $(x)$ and the probability of sanction ( $p$ ) satisfy the following condition:

$$
(1-p)(33+3 x)+p(33+3 x) * 0.2=36
$$

Thus, in the low-risk treatment ( $p=20 \%$ ), the minimum acceptable bribe offer is 4 points, while in the high-risk treatment $(p=60 \%)$, it is 13 . Since bribes cannot exceed 9 by design, in the high-risk treatment, an official's best choice is never accepting a bribe if he is a key player.

Alternatively, taking the group as a whole indicates that officials should never accept a bribe under high risk, since the expected payoff is, at best, 31.2 (i.e., when accepting the highest possible bribe of 9 and denying permission). Under low risk, the minimum acceptable bribe offer is 3 , if they deny permission, and 4 if they grant it (since granting permission entails a cost of 3 ). Therefore, regardless of whether we take the perspective of the group of officials as a whole, or that of a single official who is the key player, a bribe lower than 3 should always be rejected in the low-risk treatment, and any bribe should be rejected in the high-risk treatment. However, this situation captures a social dilemma, since a single official who is not the key player is always tempted to accept a bribe because it increases his individual payoff. The conflict between collective and individual interests is all the more sharp, as an official does not know whether or not he is the key player. Officials learn at the end of the period whether a collective sanction occurred, and this helps them update their beliefs about the choices of others. But even after a collective sanction occurs, an official cannot know for sure whether or not he is the key player.

Firms can anticipate that officials pursuing their self-interest will accept a bribe, even when it is in the interest of the group to reject it. If trustful enough, they may therefore offer a bribe to the 
official in both risk treatments. The likelihood of a bribe is, however, lower when officials face a higher risk of collective sanction, and the amount of the bribe offered is higher to compensate for the higher risk. This likelihood may also depend on the feedback received. Indeed, although firms cannot know how many bribes were accepted, and whether a collective sanction occurred in a period, they can infer how many other firms were granted permission through their own payoff. In fact, a firm's payoff is decreased by 2 points for every other firm granted permission. This information gives a signal to the firm about the number of officials acting reciprocally.

Based on the above analysis, we have the following conjectures (alternative to Conjecture 1):

Conjecture 2 (Social preferences): For a given group size, firms offer bribes more frequently but their amount is smaller in the low-risk treatments than in the high-risk treatments.

Conjecture 3 (Social preferences): For a given group size, public officials are more likely to accept bribes and grant permission in the low-risk treatments than in the high-risk treatments.

With trust and reciprocity, the group size can also influence corruptibility. The threshold condition that triggers the collective risk is the same (60\%) for small and large groups, so the threshold number of corrupt officials is 3 in small groups and 6 in large groups. An official does not know whether or not he is the key player who determines whether the threshold is reached. However, in a small group each official has a higher chance of being the key player (1 in 5) than in a large group ( 1 in 10). Therefore, officials in a small group may feel more responsible for a collective sanction than officials in a large group. This may be anticipated by firms. This analysis leads to the following conjectures:

Conjecture 4 (Social preferences): For a given risk, firms in a large group are more likely to offer a bribe, but the amount of the bribe is lower than in a smaller group.

Conjecture 5 (Social preferences): For a given risk, public officials in a large group feel less responsible for a collective sanction than in a small group. They are more likely to accept a bribe and reciprocate by granting permission to the firm.

In short, we predict the following rankings across treatments:

- $\mathrm{LL}<\mathrm{LH}$ and $\mathrm{SL}<\mathrm{SH}$ for the mean bribe amount, conditional on firms offering a bribe; 
- $\mathrm{LL}>\mathrm{LH}>\mathrm{SH}$ and $\mathrm{LL}>\mathrm{SL}>\mathrm{SH}$ for the bribing rate, the officials' acceptance and permission rates, conditional on receiving a bribe offer, and for the overall corruption rate.

Of course, if officials take into account the negative externalities of granting permission on the other firms, the difference of behavior between a small and a large group may be weakened. Indeed, in a larger group, their permission decision affects more firms and reduces efficiency to a larger extent.

\subsection{Procedures}

The experimental sessions were conducted in the computer lab of Zhejiang University in China, using the z-Tree software (Fischbacher 2007). We recruited 360 students (189 females and 171 males) from various disciplines via announcements on the bulletin board system. We conducted 18 sessions, with 20 participants in each session, including 6 sessions for each large group treatment and 3 sessions for each small group treatment. Thus, we get 6 independent observations for each treatment. Table 1 summarizes the features of the experimental sessions.

Table 1. Summary of experimental sessions

\begin{tabular}{lcccccc}
\hline Treatment & \# Sessions & Group size & Risk & \# Subjects & \# Groups & Females (\%) \\
\hline LL & 6 & 20 & $20 \%$ & 120 & 6 & 51.67 \\
LH & 6 & 20 & $60 \%$ & 120 & 6 & 55.83 \\
SL & 3 & 10 & $20 \%$ & 60 & 6 & 53.33 \\
SH & 3 & 10 & $60 \%$ & 60 & 6 & 46.67 \\
\hline Total & 18 & - & - & 360 & 24 & 52.50 \\
\hline
\end{tabular}

Upon arrival, students were randomly assigned to a terminal and received the instructions (see Appendix 1). The subjects had to answer control questions (Appendix 2) after they had read the instructions. We did not proceed until all subjects had answered all questions correctly. Like in Abbink and Hennig-Schmidt (2006), instructions were contextualized but we avoided loaded terms like "bribe" (we used instead "private payment"). At the end of each session, we recorded individual demographic characteristics, and elicited the subjects' beliefs towards trust and corruption. A few questions were taken from the World Value Survey (See Appendix 3). 
Each session lasted about 90 minutes. On average, subjects earned 49.64 (Std. Dev. 7.24) Yuan (RMB) (about \$8.5), including a RMB5 show-up fee. Earnings were paid in cash by someone who was not aware of the content of the experiment, and this was made common information in the instructions.

\section{Results}

In this section, we first consider the firms' bribing behavior before focusing on the officials' acceptance and permission decisions; next, we analyze the evolution of behavior over time, and we conclude with the analysis of payoffs. Throughout the section, we refer to Table 2, which reports summary statistics including the mean decisions of firms and officials by treatment, pairwise Mann-Whitney rank-sum tests, and Kruskal-Wallis equality-of-populations rank tests comparing the four treatments. In the non-parametric tests, the mean decision of a group of subjects across periods gives one independent observation. All tests are two-sided. We complement this analysis with an econometric analysis of individual decisions.

Table 2. Summary statistics

\begin{tabular}{|c|c|c|c|c|c|c|c|c|c|c|c|}
\hline \multirow[b]{2}{*}{ Treatments } & \multicolumn{5}{|c|}{ Means } & \multicolumn{6}{|c|}{ Tests } \\
\hline & LL & LH & SL & $\mathrm{SH}$ & Total & $\begin{array}{l}\text { LL vs. } \\
\text { LH }\end{array}$ & $\begin{array}{l}\text { LL vs. } \\
\text { SL }\end{array}$ & $\begin{array}{c}\text { SL vs. } \\
\text { SH }\end{array}$ & $\begin{array}{c}\text { LH vs. } \\
\text { SH }\end{array}$ & $\begin{array}{c}\text { LL vs. } \\
\text { SH }\end{array}$ & Total \\
\hline Bribe rate $(\%)$ & 75.33 & 70.83 & 70.67 & 68.22 & 71.87 & 0.149 & 0.423 & 0.296 & 0.521 & 0.030 & 0.199 \\
\hline Mean bribe (if bribe) & 4.70 & 4.71 & 4.64 & 5.09 & 4.75 & 1.00 & 0.749 & 0.150 & 0.337 & 0.262 & 0.533 \\
\hline $\begin{array}{l}\text { Acceptance rate }(\% \text {, if } \\
\text { received a bribe })\end{array}$ & 86.36 & 78.82 & 81.13 & 74.59 & 81.16 & 0.016 & 0.262 & 0.262 & 0.522 & 0.037 & 0.099 \\
\hline $\begin{array}{l}\text { Permission rate }(\%, \text { if } \\
\text { received a bribe })\end{array}$ & 65.12 & 59.29 & 58.81 & 51.79 & 60.06 & 0.016 & 0.055 & 0.200 & 0.078 & 0.013 & 0.015 \\
\hline $\begin{array}{l}\text { Social corruption } \\
\text { level }(\%)\end{array}$ & 47.11 & 39.44 & 40.00 & 31.22 & 40.72 & 0.004 & 0.199 & 0.064 & 0.076 & 0.004 & 0.007 \\
\hline $\begin{array}{l}\text { \# group decisions } \\
\text { exceeding threshold }(/ 180)\end{array}$ & 141 & 95 & 121 & 98 & - & 0.005 & 0.422 & 0.262 & 0.871 & 0.025 & 0.038 \\
\hline \# sanctions & 32 & 64 & 29 & 59 & & 0.004 & 0.411 & 0.004 & 0.361 & 0.004 & 0.001 \\
\hline
\end{tabular}

Notes: The social corruption level is defined as the percentage of public officials who receive a bribe offer, accept it and grant permission among all officials. The left panel reports mean values and percentages. In the right panel, the pairwise treatment comparisons report $p$-values from Mann-Whitney rank-sum tests. The last column indicates the $p$ value from Kruskal-Wallis equality-of-populations rank tests. 


\subsection{Firms' bribing decisions}

We introduce our first result:

Result 1: a) A majority of firms offer bribes. b) There is limited evidence of an influence of the group size and of the risk of collective sanction on the firms' decision to offer a bribe. c) Conditional on attempting to bribe, firms offer higher bribes in smaller groups when the risk of collective sanction is high (SH) than in larger groups under low risk (LL).

Support for Result 1. Table 2 indicates that firms offer a bribe in $71.87 \%$ of the observations. This rejects Conjecture 1 . The mean bribing percentage is the highest in the LL treatment $(75.33 \%)$, and lowest in the SH treatment (68.22\%), while the LH (70.83\%) and the SL treatments (70.67\%) lie in-between. The treatment ranking is as predicted: $\mathrm{LL}>\mathrm{LH}>\mathrm{SH}$ and $\mathrm{LL}>\mathrm{SL}>\mathrm{SH}$ but few differences are significant. The difference is only significant when we compare LL and SH (Mann Whitney test: $p=0.030)$. The higher bribing percentage when the risk of sanction is low is in line with Conjecture 2, and the higher percentage in large groups is in line with Conjecture 4, but it is the interaction between the size and the level of risk that influences firms' behavior significantly.

The mean amount of a bribe is 4.75 points. It is larger when the risk is higher, which is in line with Conjecture 2, but this is observed only in small groups (5.09 vs. 4.64, respectively) and not in large groups (4.71 vs. 4.70, respectively). Table 2 shows that no pairwise treatment comparison reaches significance. However, additional two-sample Kolmogorov-Smirnov tests indicate that the equality of distribution of the bribe amounts is rejected between LL and LH ( $p=0.002)$, LL and SL $(p=0.044)$, SL and SH $(p=0.037)$, and between LH and SH $(p=0.010)$.

Next, we proceed to an econometric analysis to understand the determinants of the firms' bribing behavior. This behavior can be broken down into two decisions: firstly, the decision to offer a bribe or not, and secondly, conditional on choosing to bribe, the choice of the amount of the bribe. We therefore estimate a Heckman two-step model. In the first step, the selection equation that explains whether a firm offers a bribe or not is estimated by means of a randomeffects Probit model (model (1)). In the second step, the conditional amount of the bribe is estimated by a GLS model (model (2)). The independent variables (defined in Table A1 in 
Appendix 4) include each treatment, with LL taken as the reference category, ${ }^{13}$ and a number of variables that control for gender (male), membership of the Chinese Communist Party $(C C P)$, experience as a student leader (leadership), distrust of strangers (Distrust), belief in a high corruption level in the country (Belief_country), justification of corruption (Justification), willingness to donate to help a group in need (Help), and risk-seeking preferences (Risk propensity). We also include a time trend (period) and a variable capturing whether the official granted permission in the previous period $\left(\right.$ permit $\left._{t-1}\right)$. The independent variables are the same as in model (2), except that permit $t_{-1}$ is excluded for identification, and the Inverse of the Mills Ratio obtained from the first equation is added to correct for a potential selection bias. In both models, robust standard errors are clustered at the group level. Table 3 reports marginal effects.

Table 3. Determinants of the bribe offer

\begin{tabular}{|c|c|c|}
\hline Independent variables & $\begin{array}{c}\text { Bribe offer (RE Probit) } \\
\text { (1) }\end{array}$ & $\begin{array}{c}\text { Bribe amount (GLS) } \\
\text { (2) }\end{array}$ \\
\hline LL Treatment & Ref. & Ref. \\
\hline LH treatment & $-0.004(0.030)$ & $0.039(0.284)$ \\
\hline SL treatment & $0.005(0.031)$ & $0.082(0.290)$ \\
\hline SH treatment & $-0.027(0.032)$ & $0.674 * *(0.290)$ \\
\hline Male & $-0.039 * * *(0.012)$ & $0.633 * * *(0.070)$ \\
\hline CCP member & $-0.002(0.013)$ & $-0.181 * *(0.077)$ \\
\hline Distrust & $-0.031 * * *(0.007)$ & $-0.179 * * *(0.040)$ \\
\hline Leadership & $-0.042 * * *(0.013)$ & $0.353 * * *(0.071)$ \\
\hline Belief_country & $0.075 * * *(0.012)$ & $0.404 * * *(0.072)$ \\
\hline Justification & $-0.007 * *(0.003)$ & $0.038 * *(0.016)$ \\
\hline Help & $-0.017 * * *(0.003)$ & $0.078 * * *(0.015)$ \\
\hline Risk propensity & $0.006(0.004)$ & $0.132 * * *(0.024)$ \\
\hline Period & $-0.004 * * *(0.001)$ & $0.046 * * *(0.004)$ \\
\hline Permit $_{t-1}$ & $0.353 * * *(0.011)$ & - \\
\hline IMR & - & $-2.230 * * *(0.127)$ \\
\hline \# obs. & 5220 & 3760 \\
\hline \# groups & 24 & 24 \\
\hline Log likelihood & -2498.543 & - \\
\hline $\mathrm{R}^{2}$ & - & 0.151 \\
\hline Wald Chi ${ }^{2}$ & 947.37 & 711.13 \\
\hline Prob $>\mathrm{Chi}^{2}$ & $<0.001$ & $<0.001$ \\
\hline
\end{tabular}

Note: The Table reports average marginal effects from a Heckman two-step model. RE stands for random-effects and GLS for Generalized Least Squares. Robust standard errors (in parentheses) are clustered at group level. ***, ** and * indicate significance at the $0.01,0.05$, and 0.1 level, respectively.

13 We take LL as the reference category because this treatment produces the highest level of corruption; therefore, it can be used to measure the curbing effect of decreased group size and increased risk of sanction on corruption. 
Controlling for individual characteristics, Table 3 indicates that the probability of offering a bribe does not differ significantly across treatments (model (1)), whereas the amount of the bribe, conditional on offering one, is significantly higher in SH than in LL (model (2)) which is in line with the result of Table2. Males, students with leadership experience, subjects who are more willing to help a group in need, but also more surprisingly those who find that corruption can be justified, are less likely to bribe; but, when they do, they offer higher bribes. Confirming that trust plays an important role in bribery, subjects who report less trust in strangers are less likely to bribe, and they offer lower bribes. Members of the CCP also offer less when offering a bribe. In contrast, subjects who believe that their country is highly corrupt are more likely to offer a bribe and bribe more, suggesting that norms matter. ${ }^{14}$ Preferences for risk do not affect the probability of bribing, but increase the amount offered.

Finally, being granted permission in the previous period encourages firms to bribe, showing the dynamics between trust and reciprocity within pairs. Firms are less likely to offer a bribe over time, but they tend to increase the amount proposed to influence the official. Overall, these results show that firms' behavior is more affected by individual characteristics than by the size of the group or the risk of the officials' collective sanction, since they bear no risk directly. We turn next to the analysis of the officials' behavior.

\subsection{Public official's corruptibility and social corruption in groups}

We predicted that officials should have a lower propensity to accept a bribe and grant permission when the group size is smaller and when the probability of a collective sanction is higher. In fact, our next result is the following:

Result 2. a) Most officials are corrupt. b) Their corruptibility, c) their trustworthiness, and d) the degree of social corruption in groups are higher in large groups under low risk of collective sanction (LL), and lower in small groups under high risk of collective sanction (SH).

14 This resonates with the findings of a recent study by Gächter and Schultz (2016) showing that individual dishonesty in the lab is directly influenced by the prevalence of rule violations in the society. 
Support for Result 2. We measure the officials' corruptibility by the acceptance rate of a bribe. As shown by Table 2, a bribe is accepted in $81.16 \%$ of the observations. In line with Conjectures 3 and 5, the acceptance rate is the highest in LL (86.36\%) and lowest in SH (74.59\%), while LH $(78.82 \%)$ and SL $(81.13 \%)$ lie in-between. The acceptance rate in the high-risk treatments is much higher than predicted, since a group of rational officials as a whole should never accept any bribe under such high risk. Moreover, while we predicted that in low-risk treatments, the lowest amount for accepting a bribe should be 3 if the official plans to deny permission and 4 if he plans to grant it, the acceptance rates in LL and SL are $67.48 \%$ and $50.45 \%$, respectively, when the amount of the bribe is less than 3 (out of 206 and 111 cases), and $75.97 \%$ and $63.28 \%$, respectively, when the bribe is less than 4 (out of 387 and 177 cases). A Kruskal-Wallis test indicates that the acceptance rate differs marginally significantly across the four treatments $(p=0.099)$. Pairwise treatment comparisons in Table 2 indicate significant differences between LL and SH $(p=0.037)$ and between LL and LH ( $p=0.016)$ but the other pairwise comparisons do not reach a standard level of significance ( $p=0.262$ for LL $v s$. SL, 0.262 for SL $v s . \mathrm{SH}$, and 0.522 for LH $v s . \mathrm{SH}$ ).

Are officials reciprocal? When accepting a bribe, permission is granted in $69.81 \%$ of the observations. So, in more than two-thirds of the time, bribery is rewarded. The permission rates when accepting a bribe are $74.42 \%, 70.65 \%, 69.77 \%$ and $61.35 \%$ in treatment LL, LH, SL and $\mathrm{SH}$, respectively. The total permission rate, irrespective of the bribery behavior of firms, is in line with Conjectures 3 and 5: it is the highest in LL (65.12\%) and lowest in SH (51.79\%), while LH $(59.29 \%)$ and SL (58.81\%) lie in-between. Kruskal-Wallis tests show significant differences in both the total permission rate $(p=0.008)$ and the permission rate if receiving a bribe offer $(p=0.015)$. Most pairwise comparisons on permission rates if receiving a bribe offer indicate (sometimes marginally) significant differences: this is the case between LL and SH ( $p=0.013), \mathrm{LL}$ and LH ( $p=0.016), \mathrm{LH}$ and SH $(p=0.078), \mathrm{LL}$ and SL $(p=0.055)$, but not between SL and SH $(p=0.200)$. 
Next, we measure social corruption by the percentage of officials in a group who receive a bribe offer, accept it and grant permission, among all officials. Indeed, whether permission is granted reflects the final realization of corruption from a macro perspective and only the permission harms other firms. As indicated in Table 2, average social corruption is highest in LL (47.11\%) and lowest in SH (31.22\%) and the difference is highly significant (Mann-Whitney test: $p=0.004)$, while the rates in LH (39.44\%) and SL (40\%) lie in-between. The effect of group size on social corruption is marginally significant in the case of a high probability of collective sanction, but not in the case of a low probability (Mann-Whitney tests: $p=0.076$ for LH $v s$. SH, but $p=0.199$ for LL $v s$. SL). The effect of the probability of collective sanction is significant for both the large and the small groups ( $p=0.004$ for LL $v s$. LH and $p=0.064$ for SL $v s . \mathrm{SH}$ ).

Therefore, the rankings of mean percentages of acceptance, permission when receiving a bribe offer, and social corruption in the four treatments are, as predicted: $\mathrm{LL}>\mathrm{LH}>\mathrm{SH}$ and LL $>$ SL $>$ SH, although not all pairwise comparisons are significant.

We consider next the evolution of corruption over time.

Result 3. The dynamics of corruption eliminates progressively the honest officials.

Support for Result 3. Figure 2 displays the evolution over time of the mean number of officials who accept a bribe and grant permission in a group, out of 10 in large groups and 5 in small groups. It shows that social corruption increases over time, except in $\mathrm{SH}$ which exhibits a more stable pattern. The large end-game effect shows that the trust-reciprocity relationship breaks down in the last period. These patterns are confirmed by Wilcoxon signed-rank tests conducted at the group level for each treatment and comparing the mean number of officials who accept a bribe and grant permission in the block of periods 1 to 15 and in the block of periods 16 to $29 .{ }^{15}$ The number of corrupt officials is significantly higher in the second block of periods in LL, LH and SL ( $p=0.028$ in each treatment), but not in $\mathrm{SH}(p=0.753)$. This phenomenon illustrates the progressive

\footnotetext{
${ }^{15}$ We exclude period 30 because of the strong end game effect.
} 
elimination of honest officials over time and supports our argument that the combination of a small group size and a high collective risk is crucial to try to escape the tragedy of corruption.

This decrease in the number of honest officials is consistent with the fact that if firms are less likely to bribe over time, the amount of the bribes offered increases significantly over time. ${ }^{16}$ As a result, officials both accept these bribes and grant the permission more frequently.

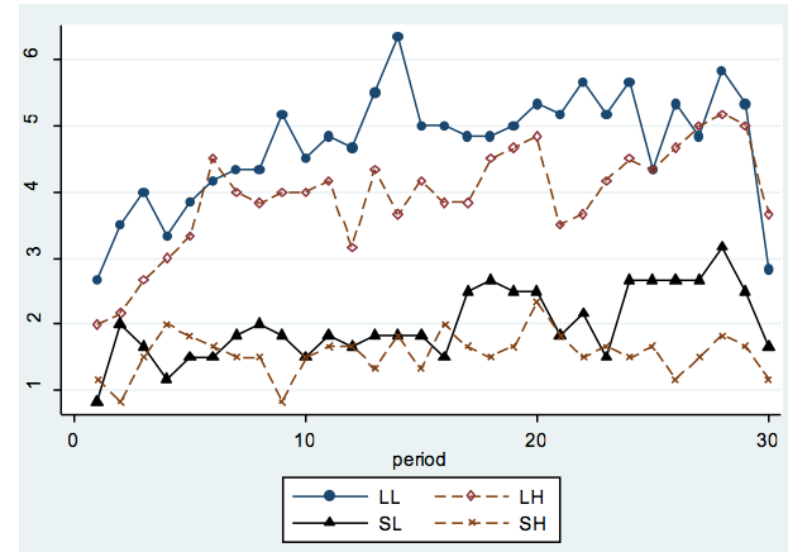

Figure 2. Evolution of social corruption over time

We next provide additional support to Results 2 and 3 by means of an econometric analysis of the determinants of officials' behavior. Table 4 reports marginal effects from two sets of regressions. The first set analyzes both the decision to accept a bribe and the permission decision conditional on receiving that bribe. It includes a Heckman two-step model to analyze the acceptance (model (1)) and permission decisions conditional on accepting a bribe (model (2)). In the first step of the Heckman model, a random-effects Probit model estimates the determinants of whether or not an official accepts a bribe offer; in the second step, a random-effects Logit model estimates whether the official grants the permission conditional on having accepted the bribe. The second set of regressions studies the unconditional permission decision, as officials can also grant

\footnotetext{
16 See the regressions reported in Table 3. Parallel to the non-parametric statistics reported on social corruption, we have conducted Wilcoxon tests on the firms' behavior. We find no significant difference in the percentage or number of firms offering a bribe between the blocks of periods 1 to 15 and 16 to 29 ( $p>0.248$ in all treatment), but the mean amount of the bribes offered is significantly higher in the second block of periods than in the first one $(p=0.028$ in LL, LH, SL), except in SH $(p=0.249)$.
} 
permission even if they do not receive a bribe offer or if they reject an offer. ${ }^{17}$ These additional regressions allow us to control for the marginal effect of receiving a bribe (models (3) and (4)). In all models, the independent variables include the amount of the bribe offered (Bribe amount) and its squared amount (Squared bribe amount). To capture non linear effects, the difference between the amount of the bribe offered in the current period and its amount in the previous period to capture reference point effects (Diff_bribe), a variable for each treatment (with LL as the reference category), and a dummy indicating whether or not a collective sanction occurred in the previous period $\left(\right.$ Sanction $\left._{t-1}\right)$. All models include the same control variables as in Table 3, except that we replace the beliefs about corruption in the country with the beliefs about the corruption norm in the group, because our game involves a coordination issue for the officials. In the second stage of the Heckman model (2), we exclude the risk-seeking preference variable for identification, and we include the IMR extracted from the selection equation (1). In models (3) and (4), we add a dummy variable capturing the marginal effect of receiving a bribe of 1 point instead of 0 . In model (4), we interact this binary variable with each treatment, and for that reason, we remove the treatment variables from the regression. The robust standard errors are clustered at the group level.

Consider first the treatment effects on the conditional decisions. Compared to LL, the effects of all the other treatments on both acceptance and conditional permission are negative. $\mathrm{LH}$ and $\mathrm{SH}$ significantly reduce the likelihood of accepting a bribe. SL is also negative, but not significant. Consistent with Conjecture 3, a higher risk of collective sanction reduces the propensity to accept a bribe (model (1)). Conditional on accepting the bribe, it is the interaction between the probability and the group size that affects the likelihood of granting permission (model (2)). Considering the

\footnotetext{
${ }^{17}$ In $10.35 \%$ of the observations, the officials grant permission, although they did not receive a bribe offer. Since it is costly to the official, this could be considered as a form of altruism toward the paired firm or as an anti-social preference against out-group firms, as it decreases their payoff.
} 
unconditional permission decisions in model (3), we find that the effects of the risk and of the group size are of comparable magnitude. ${ }^{18}$

Table 4. Determinants of officials' acceptance and permission behavior

\begin{tabular}{|c|c|c|c|c|}
\hline \multirow{3}{*}{$\begin{array}{l}\text { Independent } \\
\text { variables }\end{array}$} & \multicolumn{2}{|c|}{$\begin{array}{c}\text { Conditional on } \\
\text { receiving a bribe } \\
\text { Heckman two-stage model }\end{array}$} & \multicolumn{2}{|c|}{$\begin{array}{l}\text { Unconditional on } \\
\text { receiving a bribe }\end{array}$} \\
\hline & $\begin{array}{l}\text { Acceptance } \\
\text { RE Probit }\end{array}$ & $\begin{array}{c}\text { Permission } \\
\text { RE Logit }\end{array}$ & $\begin{array}{r}\text { Per } \\
\text { RE }\end{array}$ & $\begin{array}{l}\text { sion } \\
\text { obit }\end{array}$ \\
\hline & (1) & (2) & (3) & (4) \\
\hline Bribe (dummy) & - & - & $\begin{array}{c}-0.102 * * * \\
(0.031)\end{array}$ & $\begin{array}{c}0.076 * * \\
(0.034)\end{array}$ \\
\hline Bribe amount & $\begin{array}{c}0.113 * * * \\
(0.011)\end{array}$ & $\begin{array}{c}0.176^{* * * *} \\
(0.021)\end{array}$ & $\begin{array}{c}0.175 * * * \\
(0.011)\end{array}$ & $\begin{array}{c}0.176^{* * * *} \\
(0.011)\end{array}$ \\
\hline $\begin{array}{l}\text { Squared bribe } \\
\text { amount }\end{array}$ & $\begin{array}{c}-0.008 * * * \\
(0.001)\end{array}$ & $\begin{array}{c}-0.010 * * * \\
(0.002)\end{array}$ & $\begin{array}{c}-0.011 * * * \\
(0.001)\end{array}$ & $\begin{array}{c}-0.011 * * * \\
(0.001)\end{array}$ \\
\hline LL treatment & Ref & Ref. & Ref. & - \\
\hline LH treatment & $\begin{array}{c}-0.083 * * * \\
(0.031)\end{array}$ & $\begin{array}{l}-0.023 \\
(0.028)\end{array}$ & $\begin{array}{c}-0.049 * * \\
(0.022)\end{array}$ & - \\
\hline SL treatment & $\begin{array}{l}-0.035 \\
(0.030)\end{array}$ & $\begin{array}{l}-0.027 \\
(0.030)\end{array}$ & $\begin{array}{l}-0.046^{*} \\
(0.024)\end{array}$ & - \\
\hline SH treatment & $\begin{array}{c}-0.123 * * * \\
(0.035)\end{array}$ & $\begin{array}{c}-0.125 * * * \\
(0.034)\end{array}$ & $\begin{array}{c}-0.116 * * * \\
(0.024)\end{array}$ & - \\
\hline Bribe $* L L$ & - & - & - & Ref. \\
\hline Bribe *LH & - & - & - & $\begin{array}{l}-0.018 \\
(0.024)\end{array}$ \\
\hline Bribe $* S L$ & - & - & - & $\begin{array}{l}-0.035 \\
(0.026)\end{array}$ \\
\hline Bribe $* \mathrm{SH}$ & - & - & - & $\begin{array}{c}-0.093 * * * \\
(0.027)\end{array}$ \\
\hline Diff_bribe & $\begin{array}{c}0.017 * * * \\
(0.003)\end{array}$ & $\begin{array}{c}-0.009 * * * \\
(0.004)\end{array}$ & $\begin{array}{c}-0.005 * \\
(0.003)\end{array}$ & $\begin{array}{c}-0.005^{* *} \\
(0.003)\end{array}$ \\
\hline Sanction $_{t-1}$ & $0.029 * *$ & $-0.075 * * *$ & $-0.035 * * *$ & $-0.037 * * *$ \\
\hline Male & $\begin{array}{c}(0.013) \\
0.014\end{array}$ & $\begin{array}{c}(0.017) \\
0050 * * *\end{array}$ & $\begin{array}{c}(0.013) \\
0050 * * *\end{array}$ & $\begin{array}{c}(0.013) \\
061 * * *\end{array}$ \\
\hline CCP member & $\begin{array}{c}(0.014) \\
0.038 * *\end{array}$ & $\begin{array}{c}(0.016) \\
-0.084 * * *\end{array}$ & $\begin{array}{c}(0.013) \\
-0.050 * * *\end{array}$ & $\begin{array}{c}(0.013) \\
-0.050 * * *\end{array}$ \\
\hline Distrust & $\begin{array}{c}(0.016) \\
0.028 * * *\end{array}$ & $\begin{array}{c}(0.019) \\
0.012\end{array}$ & $\begin{array}{c}(0.015) \\
0.019 * * *\end{array}$ & $\begin{array}{c}(0.015) \\
0.019 * * *\end{array}$ \\
\hline Leadership & $\begin{array}{c}(0.007) \\
0.017\end{array}$ & $\begin{array}{c}(0.010) \\
0.045^{* * *}\end{array}$ & $\begin{array}{c}(0.007) \\
0.029 * *\end{array}$ & $\begin{array}{l}(0.007) \\
0.030 * *\end{array}$ \\
\hline Belief_exp & $\begin{array}{c}(0.013) \\
0.037 * * *\end{array}$ & $\begin{array}{c}(0.017) \\
0.006\end{array}$ & $\begin{array}{c}(0.012) \\
0.013\end{array}$ & $\begin{array}{c}(0.012) \\
0.011\end{array}$ \\
\hline Justification & $\begin{array}{c}(0.010) \\
0.011 * * *\end{array}$ & $\begin{array}{c}(0.013) \\
0.007 * *\end{array}$ & $\begin{array}{c}(0.009) \\
0.008 * * *\end{array}$ & $\begin{array}{c}(0.009) \\
0.008 * * *\end{array}$ \\
\hline Help & $\begin{array}{c}(0.002) \\
-0.011 * * *\end{array}$ & $\begin{array}{l}(0.003) \\
-0.005\end{array}$ & $\begin{array}{c}(0.002) \\
-0.008 * * *\end{array}$ & $\begin{array}{c}(0.002) \\
-0.008 * *\end{array}$ \\
\hline Risk propensity & $\begin{array}{c}(0.003) \\
0.015 * * *\end{array}$ & $\begin{array}{c}(0.003) \\
-\end{array}$ & $\begin{array}{c}(0.003) \\
0.013 * * *\end{array}$ & $\begin{array}{c}(0.003) \\
0.012 * * *\end{array}$ \\
\hline Period & $\begin{array}{c}(0.005) \\
0.001 * *\end{array}$ & $0.003 * * *$ & $\begin{array}{c}(0.004) \\
0.002 * *\end{array}$ & $\begin{array}{c}(0.004) \\
0.002 * * *\end{array}$ \\
\hline
\end{tabular}

18 Compared to LL, the marginal effect of LH does not differ from the marginal effect of SL ( $t$-test, $p=0.877)$. 


\begin{tabular}{lcccc}
\hline IMR & $(0.001)$ & $(0.001)$ & $(0.001)$ & $(0.001)$ \\
& - & -0.007 & - & - \\
\hline \# obs. & & $(0.058)$ & & \\
\# groups & 3760 & 3067 & 5220 & 5220 \\
Log likelihood & -1497.49 & 24 & 24 & 24 \\
Wald $\mathrm{Chi}^{2}$ & 471.07 & -1569.47 & -2565.05 & -2568.38 \\
Prob $>\mathrm{Chi}^{2}$ & $<0.001$ & $<36.21$ & 1621.14 & 1627.98 \\
\hline
\end{tabular}

Note: The Table reports average marginal effects. RE stands for random-effects. In the interaction terms bribe ${ }^{*} L L,{ }^{*} L H, * S L$, and $* S H$, the bribe variable is a dummy variable. Robust standard errors (in parentheses) are clustered at group level. $* * *, * *$ and $*$ indicate signficiance at the $0.01,0.05$, and 0.1 level, respectively.

Table 4 also indicates that officials are more likely to accept bribes and to grant permission when the bribe is larger, but the marginal effect of the latter is decreasing. A higher bribe in the current period, compared to that offered in the previous one, increases the willingness to accept it, but decreases the probability of granting permission, as if the official tried to raise the level of the bar over time. Model (3) shows that it is better for a firm to offer no bribe than a bribe of 1 point, since officials are more likely to deny permission when being offered such a small bribe. ${ }^{19}$ Model (4) shows that this effect is driven by officials in small groups, under a high probability of sanction.

Supporting Result 3, about the elimination of honest officials over time, we find that the probabilities of accepting bribes and granting permissions increase significantly over time. The assignment of a collective sanction in the previous period does not stop officials from accepting a bribe. On the contrary, they try to recover their loss by increasing their corruptibility, and reducing their willingness to grant permission. This increase in corruptibility can also result from a revision of beliefs about the norm prevailing in the group, since only a sanction can (imperfectly) inform about the number of corrupt officials.

The probability of acceptance is increased by CCP membership, distrust in strangers, risk preferences, beliefs that corruption can be justified and that its level is high, whereas it is decreased by higher social preferences as measured by the willingness to help others in the final

${ }^{19}$ Unsurprisingly, withdrawing the amount of the bribe and its square from model (3) changes the sign of the bribe variable that becomes positive with a marginal effect of 0.485 and a $p$-value $<0.001$ (available upon request). 
hypothetical questionnaire. The (conditional and unconditional) probability of granting permission is increased for males and student leaders, and for those subjects who justify more corruption. It is reduced by CCP membership.

\subsection{Efficiency and the "Tragedy of corruption"}

We finally consider how efficiency, measured by the sum of net payoffs, is affected by corruption. Our last result follows.

Result 4. Both firms and officials are victims of the "Tragedy of corruption", as their mean payoffs are significantly lower than payoffs obtained in the absence of corruption.

Support for Result 4. Table 5 displays the mean and standard deviation of the firms' and officials' payoffs per period. It also indicates the percentage of firms and officials who earn less than the payoff that they would have obtained in the absence of corruption (36 points) (" $\%$ lose").

Table 5. Payoffs of firms and public officials, by treatment

\begin{tabular}{cccc|ccc|ccc}
\hline \multirow{2}{*}{ Treatment } & \multicolumn{3}{c|}{ Firms' payoffs } & \multicolumn{3}{c|}{ Officials' payoffs } & \multicolumn{3}{c}{ Total payoffs } \\
\cline { 2 - 10 } & Mean Std. Dev. & $\%$ lose & Mean & Std. Dev. \% lose & Mean & Std. Dev. \% lose \\
\hline LL & 33.17 & 9.03 & 65.00 & 37.43 & 14.87 & 38.33 & 35.30 & 12.48 & 51.65 \\
LH & 33.31 & 8.80 & 65.00 & 30.58 & 17.36 & 95.00 & 31.94 & 13.83 & 48.47 \\
SL & 37.78 & 8.52 & 36.67 & 37.50 & 14.42 & 50.00 & 37.64 & 11.84 & 43.35 \\
SH & 36.98 & 8.53 & 56.67 & 31.47 & 17.19 & 86.67 & 34.22 & 13.84 & 71.67 \\
\hline Total & 34.62 & 9.00 & 58.89 & 34.16 & 16.40 & 67.22 & 34.39 & 13.23 & 63.06 \\
\hline
\end{tabular}

Table 5 indicates that corruption lowers the payoffs of both firms and officials, as compared to the level of payoffs that would be obtained in the absence of corruption in the group. This loss of efficiency characterizes the "Tragedy of corruption". Indeed, the mean payoff of firms is only 34.62 while that of officials is 34.16 , which is significantly different from 36 (Wilcoxon signedrank tests: $p=0.001$ for firms and $p<0.001$ for officials).

$58.89 \%$ of firms earn less than 36 because of the negative externalities imposed by the permission granted by officials to other firms, and because their bribes are not always reciprocated. This percentage is naturally more important in large groups $(65 \%$ in both LL and LH), compared to small groups (36.67\% in SL and $56.67 \%$ in $\mathrm{SH})(p<0.001$ for both LL $v s$. SL 
and LH vs. SH), since in large groups, each firm suffers from the negative externalities of a higher number of other firms that have been granted permission.

$67.22 \%$ of the officials also earn less than 36 , due to sanctions in some periods. This percentage is naturally much larger when the probability of a sanction is higher, because officials do not adjust their behavior sufficiently ( $95 \%$ in $\mathrm{LH}$ and $86.67 \%$ in $\mathrm{SH}$, compared to $38.33 \%$ in LL and 50\% in SL) $\left(p<0.001\right.$ for both LL vs. LH and SL vs. SH) ${ }^{20}$ Indeed, as a result of the high social corruption levels, the number of times the threshold of collective sanction is reached is 141 in LL (78.33\%), 95 in $\operatorname{LH}(52.78 \%), 121$ in SL (67.22\%), and 98 in SH (54.44\%), out of 180 group decisions per treatment (see Table2). The corresponding percentage of times a collective sanction occurred is $17.78 \%$ in LL, $35.56 \%$ in $\mathrm{LH}, 16.11 \%$ in SL and $32.78 \%$ in $\mathrm{SH}$.

\section{Discussion and conclusion}

We provide experimental evidence on corruption analyzed as a social dilemma problem in which the exchange of bribes for a favor generates an endogenous risk of collective sanction for the public officials. We show that a "Tragedy of corruption" occurs in many instances for two reasons: $i$ ) most officials cannot resist the selfish temptation of accepting bribes and granting permission to the bribers to develop a project that entails negative consequences for the other firms, and $i$ ) they are not able to coordinate with the other officials to avoid the risk of collective sanction. The corruptibility of officials and the trust-reciprocity relationship within pairs of subjects trigger the risk of collective sanction. Although corrupt players are aware of the risk of sanction, they pursue the selfish interest of their pair, instead of protecting the group by refraining from accepting bribes and granting permissions. Honest officials and firms are their victims. Hence, corruption and conditional cooperation lead to the progressive elimination of the honest

\footnotetext{
${ }^{20}$ Note that the percentage of officials earning less than 36 is higher in SL than in LL although the number of cases in which the threshold is reached is lower. This results from the actual random draws that have been more penalizing in SL than in LL.
} 
officials over time. The occurrence of collective sanctions entails a loss of efficiency in most groups. This is similar to the tragedy of the commons in environmental public goods.

Our approach in terms of social dilemma delivers results that are consistent with those of studies based on the initial game of Abbink et al. (2002) or its framed version by Abbink and Hennig-Schmidt (2006). Like them, we find that corruption increases over time, entailing an increasing loss of efficiency. A difference with this literature is that the persistence and the development of corruption are supported by a different mechanism. Indeed, in these studies corruption benefits both firms and corrupt officials, and its evolution is guided by the development of trust relationships between bribers and bribees. In contrast, in our study the mean payoffs are reduced by the development of corruption over time because of the occurrence of collective sanctions. This is explained by the social dilemma structure of our game: at his individual level, a selfish official has an incentive to deviate from the moral course of action by accepting a bribe, ignoring the negative externality of granting permission on other firms, and neglecting the negative externality associated with the increased collective risk for the other officials.

We acknowledge a number of limitations of our study. Using laboratory data to study corruption allows us to control the environment and generate data on a usually secretive activity, but it also raises the question of the external validity of our findings. First, the generalizability of lab evidence is a source of a lively discussion in the profession (e.g., Levitt and List, 2007, vs. Falk and Heckman, 2009; Camerer, 2015). Importantly, our aim is not to make precise point predictions on the intensity of corruption in real settings and there is a consensus on the external qualitative validity of lab findings (Fréchette and Schotter, 2015). Moreover, several recent studies have shown that dishonesty in the lab is correlated with cheating in the field (List, 2009; Hanna and Wang, 2015; Cohn et al., 2016; Dai et al., 2016; Gächter and Schultz, 2016). This makes us relatively confident about the external validity of the directional effects that we identified in the lab. A second potential limitation is that our study has been conducted in China, a highly corrupt 
country. ${ }^{21}$ It would be interesting to study how replicating this experiment in a country with different social norms would affect its results. Finally, the design of a lab experiment requires making simplifications. In our game a collective sanction affects the officials only in the period when it occurs, and it does not impact firms. We did it on purpose since introducing definitive exclusion with a non-negligible probability would not allow us to compare behavior across groups over time. Moreover, since our mechanism does not require to detect individual dishonesty, bribers cannot be punished. But we acknowledge that in real settings firms may be affected indirectly by the collapse of a group of officials, as they have to start a relationship with new officials, which may generate transaction costs. We could think of extensions of our game in which the whole society would be impacted by the detection of fraud, including firms and the other citizens, or in which a collective sanction would lead to rematch firms and officials.

Understanding the nature of corruption and its fundamental determinants is the basis for effective anti-corruption interventions. Several countries have been investing great efforts into reducing corruption by designing policies based on the view that corruption obeys a principalagent logic, with relatively limited success (see Persson et al., 2013, for a discussion). With the above mentioned limitations in mind, analyzing the social dilemma features of corruption may suggest complementary policy instruments. For example, we find that smaller groups tend to experience, on average, less corruption than larger groups, which suggests organizing officials into smaller units to increase the feeling of responsibility. Making officials and potential bribers more aware of the risk of collective sanctions triggered by corruption is also a possible avenue. Our experiment stresses, however, that it may be necessary to combine these two interventions, as each measure in isolation does not always produce significant effects. Our approach also recommends a number of extensions, in particular reconsidering measures that have been shown to sustain

21 Its corruption perception index ranks China 83 out of 168 countries in 2015 ( 1 being the less corrupt) and its bribe payers index (the likelihood of firms from the country to bribe when operating abroad) ranks it 27 out of 28 countries in 2011 (Transparency International, 2016). The importance of personalized networks of influence and mutual obligations certainly facilitates bribery (see Hennig-Schmidt and Gong, 2014, on Guanxi culture and corruption). 
cooperation in public goods games, such as peer punishment or rewards, communication or the election of group leaders. This is left for further investigation.

\section{References}

Abbink, K., 2004. "Staff rotation as an anti-corruption policy: an experimental study", European Journal of Political Economy, 20: 887-906.

Abbink, K., 2005. "Fair Salaries and the Moral Costs of Corruption", In B. Kokinov (Ed.), Advances in cognitive economics. Sofia: NBU Press.

Abbink, K., Dasgupta, U., Gangadharan, L., and Jain, T., 2014. "Letting the Briber Go Free: An Experiment on Mitigating Harassment Bribes", Journal of Public Economics, 111, 17-28.

Abbink, K., Hennig-Schmidt, H., 2006. "Neutral versus Loaded Instructions in a Bribery Experiment", Experimental Economics, 9(2): 103-121.

Abbink, K., Irlenbusch, B., Renner, E., 2002. “An Experimental Bribery Game”, Journal of Law, Economics, and Organization, 18(2): 428-454.

Abbink, K., Serra, D. 2012. “Anticorruption Policies: Lessons from the Lab”, Research in Experimental Economics, 15: 77-115.

Aidt, T.S. 2003. "Economic Analysis of Corruption: A Survey", The Economic Journal, 113 (491): F632-F652.

Alesina, A., Angeletos, G. M. 2005. "Corruption, inequality and fairness", Journal of Monetary Economics, 52(7): 1227-1244.

Armantier, O., Boly, A. 2011, “A Controlled Field Experiment on Corruption”, European Economic Review, 55(8): 1072-1082.

Azfar, O., Nelson, W. 2007. "Transparency, Wages, and the Separation of Powers: An Experimental Analysis of Corruption”, Public Choice, 130: 471-493.

Banuri, S., Eckel, C., 2015. "Cracking down on bribery”, Social Choice and Welfare, 45 (3): 579600.

Barr, A., Lindelow, M., Serneels, P. 2009. "Corruption in public service delivery: An experimental analysis", Journal of Economic Behavior \& Organization, 72(1): 225-239.

Balafoutas, L., 2011. "Public Beliefs and Corruption in a Repeated Psychological Game", Journal of Economic Behavior \& Organization, 78(1): 51-59.

Becker, Gary S., Stigler, G. J. 1974. "Law Enforcement, Malfeasance, and Compensation of Enforcers", Journal of Legal Studies, 3(1): 1-18.

Berninghaus, S. K., Haller, S., Krüger, T., Neumann, T., Schosser, S., Vogt, B. 2013. "Risk Attitude, Beliefs, and Information in a Corruption Game-An Experimental Analysis", Journal of Economic Psychology, 34: 46-60.

Boyd, R., Richerson, P. J. 1988. "The Evolution of Reciprocity in Sizable Groups”, Journal of Theoretical Biology, 132: 337-356. 
Camerer, C.F., 2015. "The Promise and Success of Lab-Field Generalizability in Experimental Economics: A Critical Reply to Levitt and List", in Fréchette, G.R., and Schotter, A. (Eds.). Handbook of Experimental Economic Methodology, Oxford: Oxford University Press, 249-295.

Chen, X., Perc, M. 2014. "Excessive abundance of common resources deters social responsibility", Scientific Reports, 4: 4161.

Cohn, A., Maréchal, M.A., Noll, T., 2016. "Bad Boys: How Criminal Identity Salience Affects Rule Violation", Forthcoming in Review of Economic Studies.

Dai, Z., Galeotti, F., Villeval, M.C., 2016. "Cheating in the Lab Predicts Fraud in the Field: An Experiment in Public Transportations", Forthcoming in Management Science.

Dannenberg, A., Löschel, A., Paolacci, G., Reif, C., Tavoni, A., 2015. "On the Provision of Public Goods with Probabilistic and Ambiguous Thresholds", Environmental and Resource Economics, 61(3): 365-383.

Dimant, E., Schulte, T., 2016. "The Nature of Corruption: An Interdisciplinary Perspective", German Law Journal, 17(1): 53-72.

Di Tella, R., Schargrodsky, E., 2003. "The Role of Wages and Auditing during a Crackdown on Corruption in the City of Buenos Aires", Journal of Law and Economics, 46(1): 269-292.

Dong, B., Dulleck, U., Torgler, B. 2012. “Conditional Corruption”, Journal of Economic Psychology, 33(3): 609-627.

Eckel, C., Grossman, P. 2008. "Forecasting Risk Attitudes: An Experimental Study Using Actual and Forecast Gamble Choices", Journal of Economic Behavior and Organization, 68(1): 1-17.

di Falco, S., Magdalou, B., Masclet, D., Villeval, M.C., Willinger, M. 2016. "Can transparency of information reduce embezzlement? An experiment in Tanzania”, IZA Discussion Paper 9925, Bonn.

Falk, A., Heckman, J., 2009. "Lab Experiments are a Major Source of Knowledge in the Social Sciences", Science, 326(5952): 535-538.

Fatas, E., Morales, A.J., Ubeda, P., 2010. "Blind justice: An experimental analysis of random punishment in team production", Journal of Economic Psychology, 31: 358-373.

Fehr, E., Gächter, S., 2000. "Cooperation and Punishment in Public Goods Experiments", American Economic Review, 90 (4): 980-994.

Ferraz, C., Finan, F., 2011. "Electoral Accountability and Corruption: Evidence from the Audits of Local Governments”, The American Economic Review, 101: 1274-1311.

Fischbacher, U. 2007. "z-Tree: Zurich Toolbox for Ready-Made Economic Experiments", Experimental Economics, 10(2): 171-178.

Fischbacher, U., Gächter, S. 2010, "Social Preferences, Beliefs, and The Dynamics of Free Riding in Public Good Experiments", American Economic Review, 100: 541-556.

Fréchette, G.R., Schotter, A. (Eds.), 2015. Handbook of Experimental Economic Methodology, Oxford: Oxford University Press, 477 p.

Gächter, S., Herrmann, B. 2009. "Reciprocity, Culture, and Human Cooperation: Previous Insights and A New Cross-cultural Experiment", Philos. Trans. Roy. Soc. B - Biol. Sci, 364: 791-806.

Gächter, S., Schultz, J.F. 2016. "Intrinsic honesty and the prevalence of rule violations across societies”, Nature, 531, 24 March: 496-499. 
Gintis, H., Bowles, S., Boyd, B., Fehr, E. (Eds.) 2005. Moral Sentiments and Material Interests, The Foundations for Cooperation in Economic Life, Cambridge, MA: MIT Press.

Hamburger, H., Guyer, M., Fox, J. 1975. "Group size and cooperation”, Journal of Conflict Resolution, 19: 503-31.

Hanna, R., Wang, S.Y., 2015. "Dishonesty and Selection into Public Service”, Working paper, Harvard University.

Hennig-Schmidt, H., Gong, H., 2014. "Sensitivity to Corruption - An Experimental Investigation in China", Unpublished paper.

Isaac, R. M., Walker, J. M., 1988. "Group size effects in public goods provision: The voluntary contributions mechanism”, The Quarterly Journal of Economics, 103(1): 179-199.

Isaac, R. M., Walker, J. M., Williams, A. W. 1994. "Group size and the voluntary provision of public goods: experimental evidence utilizing large groups", Journal of Public Economics, 54(1): 1-36.

Jain, A. K., 2001. “Corruption: A Review”, Journal of Economic Surveys, 15(1): 71-121.

Jiang, S., Chen, Y., 2016, "The dilemma of corruption: A lab experiment on the nature of corruption” (in Chinese), Economic Research Journal, 51(1):127-140.

Lambsdorff, J. G., 2006. "Causes and Consequences of Corruption: What Do We Know from a Cross-Section of Countries?" in S. Rose-Ackerman (ed.), International Handbook on the Economics of Corruption, 3-51. Cheltenham, UK: Edward Elgar.

Levitt, S., List, J.A., 2007. "What Do Laboratory Experiments Social Preferences Reveal About the Real World", Journal of Economic Perspectives, 21(2): 153-174.

List, J.A., 2009. "The economics of open air markets”, NBER Working Paper 15420.

MacMullen, R., 1988. Corruption and the Decline of Rome, Yale University Press.

Mauro, P. 1995. "Corruption and Growth”, The Quarterly Journal of Economics, 110(3): 681-712.

Milinski, M., Sommerfeld, R. D., Krambeck, H. J., Reed, F. A., Marotzke, J., 2008. "The Collective-Risk Social Dilemma and the Prevention of Simulated Dangerous Climate Change", Proceedings of the National Academy of Sciences, 105(7): 2291-2294.

Nosenzo, D., Quercia, S., Sefton, M. 2015. "Cooperation in Small Groups: The Effect of Group Size”, Experimental Economics, 18(1): 4-14.

Olken, B. A. 2007. "Monitoring Corruption: Evidence from a Field Experiment in Indonesia", Journal of Political Economy, 115(2): 200-249.

Olson, M. 1965. The logic of collective action: Public goods and the theory of groups. Cambridge, MA: Harvard University Press.

Ostrom, E. 1990. Governing the Commons: The Evolution of Institutions for Collective Action. Cambridge, UK: Cambridge University Press.

Ostrom, E. 1998. "A Behavioral Approach to the Rational Choice Theory of Collective Action", American Political Science Review, 92 (1): 1-22.

Persson, A., Rothstein, B., Teorell, J. 2013. "Why Anticorruption Reforms Fail-Systemic Corruption as a Collective Action Problem", Governance, 26(3): 449-471.

Persson, T., Tabellini, G. 2004. "Constitutions and Economic Policy", Journal of Economic Perspectives, 18(1): 75-98. 
Putterman, L., Tyran, J.R., Kamei, K., 2011. "Public Goods and Voting on Formal Sanction Schemes", Journal of Public Economics, 95(9-10): 1213-1222.

Rauch, J. E., Evans, P. B. 2000. "Bureaucratic Structure and Bureaucratic Performance in Less Developed Countries", Journal of Public Economics, 75(1): 49-71.

Rose-Ackerman, S., 1975. “The Economics of Corruption”, Journal of Public Economics, 4(2): 187-203.

Rose-Ackerman, S., 1999. Corruption and Government: Causes, Consequences, and Strategies for Reform. Cambridge: Cambridge University Press.

Sally, D. 1995. "Conversation and Cooperation in Social Dilemmas: A Meta-Analysis of Experiments from 1958 to 1992", Rationality and Society, 7(1): 58-92.

Santos, F. C., Pacheco, J. M. 2011. "Risk of Collective Failure Provides an Escape from the Tragedy of the Commons", Proceedings of the National Academy of Sciences, 108(26): 1042110425.

Serra, D. 2006. "Empirical Determinants of Corruption: A Sensitivity Analysis", Public Choice, 126: $225-256$.

Serra, D., 2012. "Combining Top-Down and Bottom-Up Accountability: Evidence from a Bribery Experiment”, Journal of Law, Economics, and Organization, 28(3), 569-587.

Shleifer, A., Vishny, R. W. 1993. "Corruption”, The Quarterly Journal of Economics, 108 (3): 599-617.

Svensson, J. 2005. "Eight Questions about Corruption", Journal of Economic Perspectives, 19 (3): $19-42$

Tavoni, A., Dannenberg, A., Kallis, G., Löschel, A., 2011. "Inequality, Communication, and the Avoidance of Disastrous Climate Change in a Public Goods Game", Proceedings of the National Academy of Sciences, 108(29): 11825-11829.

Transparency International, 2016. http://www.transparency.org/cpi2015. Accessed 5 August 2016.

Treisman, D. 2000. "The causes of corruption: a cross-national study", Journal of Public Economics, 76(3): 399-457.

Treisman, D. 2007. "What have we learned about the causes of corruption from ten years of crossnational research?", Annual Review of Political Science, 10: 211-244.

Van Huyck, J. B., Battalio, R. C., Beil, R. O. 1990. “Tacit Coordination Games, Strategic Uncertainty, and Coordination Failure", American Economic Review, 80(1): 234-248.

Van Rijckeghem, C., Weder, B. 2001. "Bureaucratic Corruption and the Rate of Temptation: How Much do Wages in the Civil Service Affect Corruption?", Journal of Development Economics, 65(2): 307-331.

Van Veldhuizen, R. 2013. "The Influence of Wages on Public Officials' Corruptibility: A Laboratory Investigation”, Journal of Economic Psychology, 39: 341-356.

Wang, Z. 2002. The "Periodic Law" of Rise and Fall of Dynasties in Ancient China. Theory Journal, 1: 101-106.

Weimann, J., Brosig-Koch, J., Hennig-Schmidt, H., Keser, C., Stahr, C. (2012). Public-good experiments with large groups, mimeo.

Zelmer, J. 2003. "Linear public goods experiments: A meta-analysis", Experimental Economics, 6(3): 299-310. 
Appendix 1. Instructions for the SL treatment (group size $=10$, probability of failure $=\mathbf{2 0} \%$ ) (The instructions for other treatments are similar except for the parts into brackets). Translated from Chinese.

Welcome to this experiment on decision-making in economics. During this session, your earnings will depend on your decisions, on the decisions of other participants in this session and on random events. It is important that you read these instructions carefully.

The experiment consists of two independent parts. At the end of the experiment, you will be paid the sum of your earnings in the two parts.

During the experiment, your earnings are counted in points. Each of you is assigned an account at the beginning of the experiment which initial value is 0 point. During the experiment, if you make a gain, the amount will be added to your account; if you make a loss, the amount will be deducted from your account. At the end of the session, your earnings in points will be converted into RMB, according to the following conversion rate:

$$
100 \text { points }=\text { RMB } 5
$$

In addition, you will receive RMB 5 for showing up on time. Your earnings will be paid in cash at the end of the session, individually and confidentially, by someone who is not aware of the content of the experiment.

All your decisions are anonymous. You will never enter your name in the computer. During the experiment you are not allowed to communicate with other participants, and the use of telephones is strictly forbidden.

If you have any question, please raise your hand. One of us will come to you to answer your question in private.

\section{Part 1}

During this part, you should select the gamble you would like to play among six different gambles. The six different gambles are listed below.

○ You must select one and only one of these gambles.

- To select a gamble, please click the corresponding box.

- Each gamble has two possible outcomes (Event A or Event B) with a given chance of occurrence. Your compensation for this part will be determined by:

- the gamble you selected and

- the event that occurs.

For example, if you select Gamble 4 and Event B occurs, you will lose 10 points. If Event A occurs, you will earn 170 points.

For every gamble, each event has a $50 \%$ chance of occurring. At the end of the session, the computer program will randomly determine which event will happen. The computer program will randomly draw a number from 1 to 10 to determine this event. If the number drawn is 1, 2, 3, 4 or 5, Event A will occur. If the number is a $6,7,8,9$ or 10 , Event $\mathrm{B}$ will occur.

On your computer screen, you will have to click the box corresponding to your preferred gamble as indicated below:

\begin{tabular}{|c|c|c|c|c|}
\hline Gamble & Event & Payoff & Chance & Your choice \\
\hline \multirow{2}{*}{1} & $\mathrm{~A}$ & 50 & $50 \%$ & \\
\cline { 2 - 4 } & $\mathrm{B}$ & 50 & $50 \%$ & \\
\hline \multirow{2}{*}{2} & $\mathrm{~A}$ & 90 & $50 \%$ & \\
\cline { 2 - 4 } & $\mathrm{B}$ & 30 & $50 \%$ & \\
\hline
\end{tabular}




\begin{tabular}{|c|c|c|c|c|}
\hline \multirow{2}{*}{3} & A & 130 & $50 \%$ & \multirow{2}{*}{} \\
\cline { 2 - 4 } & B & 10 & $50 \%$ & \\
\hline \multirow{2}{*}{4} & A & 170 & $50 \%$ & \\
\cline { 2 - 4 } & B & -10 & $50 \%$ & \\
\hline \multirow{2}{*}{5} & A & 210 & $50 \%$ & \\
\cline { 2 - 4 } & B & -30 & $50 \%$ & \\
\hline \multirow{2}{*}{6} & A & 220 & $50 \%$ & \\
\cline { 2 - 4 } & B & -40 & $50 \%$ & \\
\hline
\end{tabular}

\section{Part 2}

This part consists of $\mathbf{3 0}$ rounds. In each round you will face the same decision situation. At the end of the experiment you will receive a payoff that is the sum of your earnings in each round.

In this part, you are in an interactive decision situation between a firm and a public official. The firm wishes to run a project which causes negative consequences to other firms. In each round, the public official must decide whether or not to grant the permission to the firm to run this project. Prior to this, the firm can offer a private payment to the public official, who can accept or reject the offer.

All the participants are randomly divided into two independent groups of 10 participants. Therefore, you are in a group of 10 participants. $[L L$ and $L H$ : All the participants are in a group of 20 participants.]

There are two types of participants: firms and public officials. There are 5 firms and 5 public officials in each group. [There are 10 firms and 10 public officials in the group.] At the beginning of the experiment, the type of each participant is randomly drawn. The type remains unchanged throughout the experiment. In the first round, pairs of participants are matched randomly. One firm and one public official are matched to one another. Participants do not know whom they interact with. The pairs also remain unchanged throughout the experiment. You will always interact with the same person but you will not know his identity.

In each round, three stage decisions will be made. The process in each round is the following.

Stage 1:

First, the firm decides whether or not to offer a private payment to the public official. If the firm decides not to offer a private payment, he must enter "0" in the blank box on the computer screen. In this case both the firm and the public official's accounts remain unchanged.

If the firm offers a private payment, he can choose an amount between $1,2,3,4,5,6,7,8$ or 9 points. In this case, the account of the firm is reduced by a transfer fee of 1 point regardless of whether the offer is accepted by the public official or not.

Stage 2:

If the firm has offered a private payment, the public official decides on whether he accepts or rejects the offered private payment.

- If the public official accepts the private payment, then the account of the firm is reduced by the amount proposed. The public official's account is increased by the triple of the amount that is paid by the firm.

- If the public official rejects the private payment, then the accounts remain unchanged except that the transfer fee of 1 point from stage 1 has still to be paid by the firm.

Stage 3:

Regardless of whether he has received or not a private payment, the public official has to choose whether or not to grant the permission to the firm. 
$\circ$ If the public official does not grant the permission, then his account and the account of the firm matched with him are increased by 36 points each. The accounts of the other participants in the group are not changed by this decision.

$\circ \quad$ If the public official grants the permission, then the firm's account is increased by 56 points, whereas the public official's account is increased by 33 points. The account of each of the other firms in the group is decreased by 2 points.

After stage 3, the round ends and a new round starts automatically.

However, in every round, a collective failure may occur. When a collective failure occurs, all the public officials in the group lose $80 \%$ of their earnings in the round (including the payoff from the project and the transfer from the firms). The earnings of the firms are not affected by a collective failure.

Whether the collective failure happens or not depends on the number of officials who have accepted a private payment during the round and on a random event.

In the group, if there are less than $\mathbf{3}$ officials who accepted a private payment from a firm, a collective failure cannot happen. If there are 3 or more officials who accepted a private payment from a firm, then a collective failure happens with 2 chances out of 10. In this case, the computer program randomly determines whether the collective failure occurs or not.

[SH: In the group, if there are less than 3 officials who accepted a private payment from a firm, a collective failure cannot happen. If there are 3 or more officials who accepted a private payment from a firm, then a collective failure happens with 6 chances out of 10. In this case, the computer program randomly determines whether the collective failure happens or not.]

[ $L L:$ In the group, if there are less than 6 officials who accepted a private payment from a firm, a collective failure cannot happen. If there are 6 or more officials who accepted a private payment from a firm, then a collective failure occurs with 2 chances out of 10. In this case, the computer program randomly determines whether the collective failure happens or not.]

[ $L H$ : In the group, if there are less than 6 officials who accepted a private payment from a firm, a collective failure cannot happen. If there are $\mathbf{6}$ or more officials who accepted a private payment from a firm, then a collective failure occurs with 6 chances out of 10. In this case, the computer program randomly determines whether the collective failure happens or not.]

At the end of the round, the officials are informed on whether a collective failure occurred or not.

The firm's decision interface on the computer screen is similar to the following screenshot:

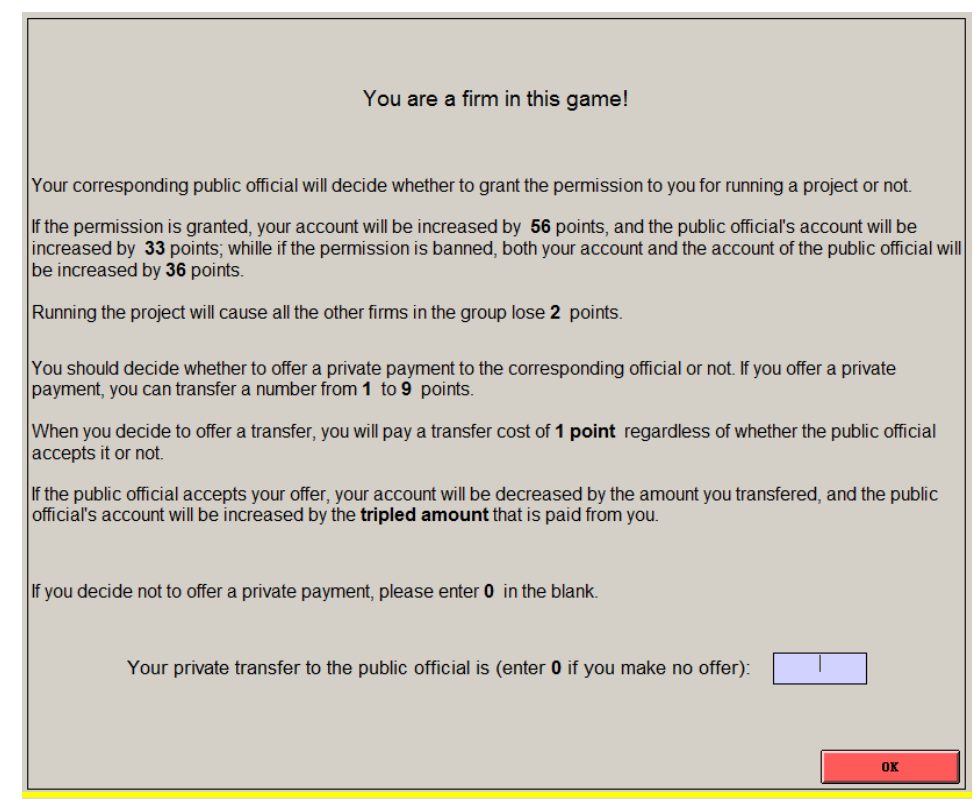


The public official's decision on the computer screen is similar to the following screenshot when the firm has offered a private transfer:

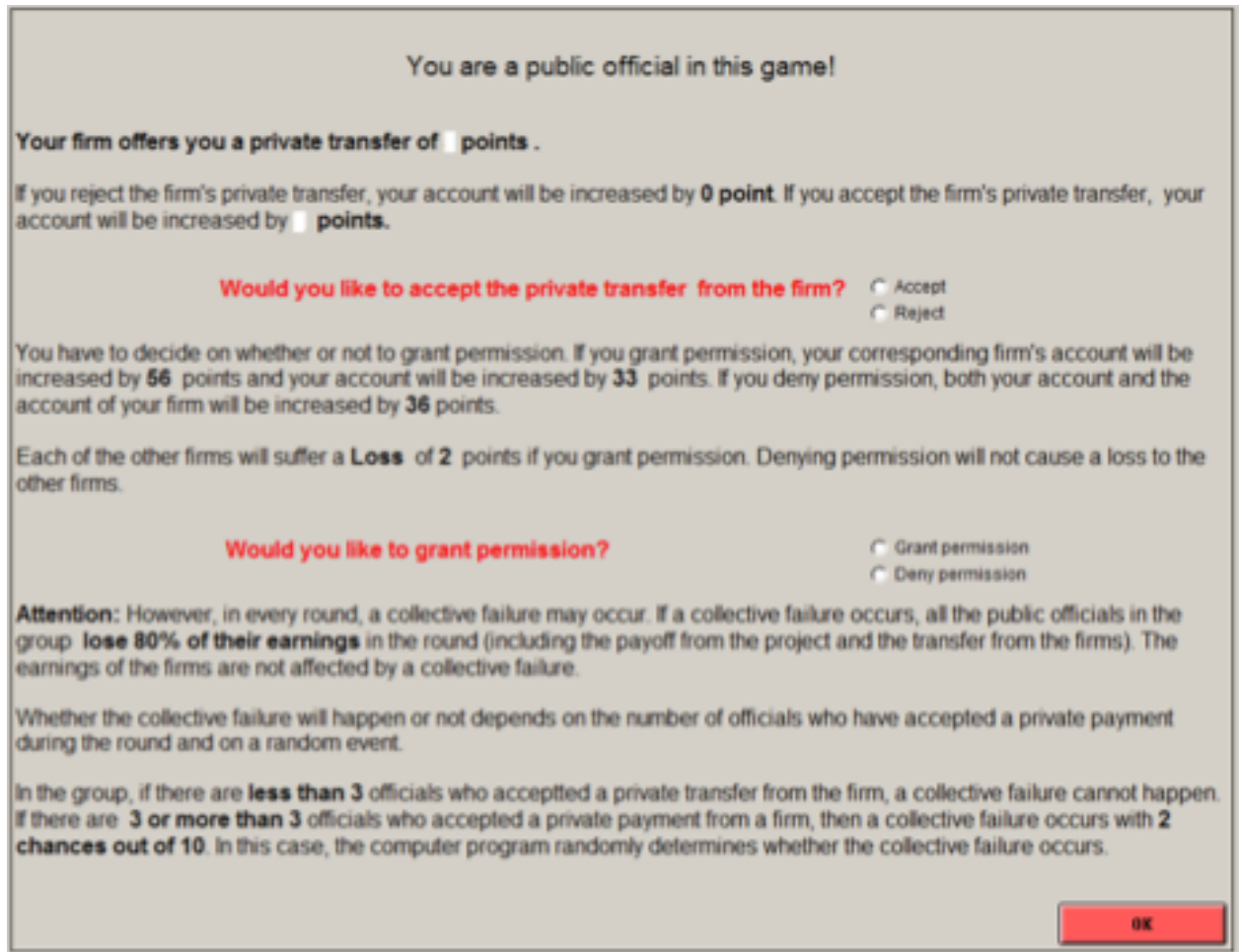

The public official's decision interface on the computer screen is similar to the following screenshot when the firm has not offered a private transfer:

You are a public official in this game!

Your firm did not offer you a private transfer.

You have to decide on whether or not to grant permission. If you grant permission, your firm's account will be increased by 56 points and your account will be increased by 33 points. If you deny permission, both your account and the account of your firm will be increased by 36 points

Each of the other firms will suffer a Loss of 2 points if you grant permission. Denying permission will not cause a loss to the other firms.

$$
\text { Would you like to grant permission? } C \text { Grant permission }
$$

$$
C \text { Deny permission }
$$

Attention: However, in every round, a collective failure may occur. If a collective failure occurs, all the public officials in the group lose $80 \%$ of their earnings in the round (including the payoff from the project and the transfer from the firms) The earnings of the firms are not affected by a collective failure.

Whether the collective failure will happen or not depends on the number of officials who have accepted a private payment during the round and on a random event.

In the group, if there are less than $\mathbf{3}$ officials who acceptted a private transfer from the firm, a collective failure cannot happen. If there are 3 or more than 3 officials who accepted a private payment from a firm, then a collective failure occurs with 2 chances out of 10 . In this case, the computer program randomly determines whether the collective failure occurs.

You can find the different possible payoffs in each round for a paired firm and public official in the following payoff tables. 
Table A. Payoffs if the firm does not offer a private transfer

Table B. Payoffs if the public official rejects a private transfer

\begin{tabular}{|l|c|c|}
\hline \multirow{2}{*}{ Decision of the public official } & \multicolumn{2}{|c|}{ Permission granted } \\
\cline { 2 - 3 } & No & Yes \\
\hline Payoff of the firm & 36 & 56 \\
\hline Payoff of the public official & 36 & 33 \\
\hline Payoff of the public official if a collective failure occurs & 7.2 & 6.6 \\
\hline Loss of each other firms & 0 & -2 \\
\hline \multirow{2}{*}{ Decision of the public official } & \multicolumn{2}{|c|}{ Permission granted } \\
\cline { 2 - 3 } & No & Yes \\
\hline Payoff of the firm & 35 & 55 \\
\hline Payoff of the public official & 36 & 33 \\
\hline Payoff of the public official if a collective failure occurs & 7.2 & 6.6 \\
\hline Loss of each other firms & 0 & -2 \\
\hline
\end{tabular}

Table C. Payoffs if the public official accepts a private transfer and permission is granted

\begin{tabular}{|c|c|c|c|c|c|c|c|c|c|}
\hline Private payment & 1 & 2 & 3 & 4 & 5 & 6 & 7 & 8 & 9 \\
\hline $\begin{array}{l}\text { Payoff of the firm } \\
\text { (56-Private payment-1) }\end{array}$ & 54 & 53 & 52 & 51 & 50 & 49 & 48 & 47 & 46 \\
\hline Loss of each other firms & -2 & -2 & -2 & -2 & -2 & -2 & -2 & -2 & -2 \\
\hline $\begin{array}{l}\text { Payoff of the public official } \\
(33+3 \times \text { Private payment })\end{array}$ & 36 & 39 & 42 & 45 & 48 & 51 & 54 & 57 & 60 \\
\hline $\begin{array}{l}\text { Payoff of the public official if } \\
\text { collective failure occurs }\end{array}$ & 7.2 & 7.8 & 8.4 & 9 & 9.6 & 10.2 & 10.8 & 11.4 & 12 \\
\hline
\end{tabular}

Table D. Payoffs if the public official accepts a private transfer and permission is not granted

\begin{tabular}{|l|c|c|c|c|c|c|c|c|c|}
\hline Private payment & 1 & 2 & 3 & 4 & 5 & 6 & 7 & 8 & 9 \\
\hline $\begin{array}{l}\text { Payoff of the firm } \\
\text { (36-Private payment-1) }\end{array}$ & 34 & 33 & 32 & 31 & 30 & 29 & 28 & 27 & 26 \\
\hline \begin{tabular}{l} 
Loss of each other firms \\
\hline $\begin{array}{l}\text { Payoff of the public official } \\
(36+3 \times \text { Private payment })\end{array}$
\end{tabular} & 39 & 42 & 45 & 48 & 51 & 54 & 57 & 60 & 63 \\
\hline $\begin{array}{l}\text { Payoff of the public official if } \\
\text { collective failure occurs }\end{array}$ & 7.8 & 8.4 & 9 & 9.6 & 10.2 & 10.8 & 11.4 & 12 & 12.6 \\
\hline
\end{tabular}

\section{Summary}

- You interact with the same persons throughout the experiment.

- The firm decides on whether or not to offer a private transfer to the public official and if so, he chooses the amount of the private transfer.

- If the firm has offered a private transfer, the public official decides to accept or reject this offer.

- The public official decides to grant or not the permission to run the project.

- A collective failure may occur that affects all the public officials, depending on the number of public officials accepting a private payment and on a random event. 


\section{Part 3 and end of the session}

In this part we thank you for answering several questions about you and your opinions. All your answers are anonymous and will be kept confidential. We appreciate if you answer all these questions sincerely.

At the end of part 3, the computer program will calculate and display your total earnings from part 1 and part 2. 


\section{Appendix 2. Understanding questionnaire for all treatments}

Before we start the experiment, you have to answer several questions about the experiment. You will not be allowed to start the experiment until you answer them correctly. You can ask us for help but you are not allowed to copy the answers of others.

1. Suppose you are a public official in the game. Your paired firm did not offer you a private transfer. You banned the permission. At the same time, all the other public officials accepted a private transfer and they all granted the permission.

(1) What is the chance of collective failure in this situation? (Please enter 0 if a collective failure will not happen for sure, or choose a number from 1 to 10 , indicating the number of chances out of 10)

(2) If a collective failure does not happen in this round, what is your payoff in this round?

(3) If a collective failure happens in this round, what is your payoff in this round?

2. Suppose you are a public official in the game. Your paired firm offered you a private transfer of 3 points. You accepted the transfer and banned the permission. At the same time, there are five other public officials in the group who accepted a private transfer and granted the permission. The remaining firms did not provide a private transfer and their paired public officials all banned the permission.

(1) What is the chance of collective failure in this situation? (Please enter 0 if a collective failure will not happen for sure, or choose a number from 1 to 10 , indicating the number of chances out of 10)

(2) If a collective failure does not happen in this round, what is your payoff in this round?

(3) If a collective failure happens in this round, what is your payoff in this round?

3. Suppose you are a public official in the game. Your paired firm offered you a private transfer of 6 points. You accepted the transfer and granted the permission. At the same time, all the other public officials in the group rejected the private transfer from their paired firms and banned the permission.

(1) What is the chance of collective failure in this situation? (Please enter 0 if a collective failure will not happen for sure, or choose a number from 1 to 10 , indicating the number of chances out of 10)

(2) What is your payoff in this round?

4. Suppose you are a public official in the game. Your paired firm offered you a private transfer of 9 points. You accepted the transfer and granted the permission. At the same time, all the other public officials in the group accepted a private transfer from their paired firms and granted the permission.

(1) What is the chance of collective failure in this situation? (Please enter 0 if a collective failure will not happen for sure, or choose a number from 1 to 10, indicating the number of chances out of 10)

(2) If a collective failure does not happen in this round, what is your payoff in this round?

(3) If a collective failure happens in this round, what is your payoff in this round?

5. Suppose you are a firm in the game. You offered a private transfer of 5 points to your paired public official. The official accepted your transfer and granted the permission. At the same time, three other officials in the group accepted a private transfer from their paired firms and granted the permission. The remaining public officials in the group did not receive a private transfer and they all banned the permission.

What is your payoff in this round?

6. Suppose you are a firm in the game. You did not offer a private transfer to your paired public official. The official banned the permission. At the same time, five other public officials in the group accepted a 
private transfer from their paired firms and granted the permission. The remaining public officials in the group rejected a private transfer and banned the permission.

What is your payoff in this round?

7. Suppose you are a firm in the game. You offered a private transfer of 8 points to your paired public official. The official accepted the transfer and banned the permission. At the same time, none of the other firms in the group offered a private transfer to the paired public officials. All the other public officials granted the permission.

What is your payoff in this round?

8. Suppose you are a firm in the game. You offered a private transfer of 2 points to your paired public official. The official accepted the transfer and granted the permission. At the same time, five other public officials in the group accepted a private transfer and three of them granted the permission while the two others banned the permission. All the remaining public officials either did not receive a private transfer or rejected a private transfer and they all banned the permission.

What is your payoff in this round? 


\section{Appendix 3. Post experimental questionnaire}

1. What is your age? years

2. What is your gender? 1. Female 2. Male

3. What education level did you achieve?

1. First year in College

2. Second year in College

3. Third year in College

4. Fourth year in College

5. Master degree

6. Doctoral degree

4. Your study discipline:

1. Business, Economics or Management

2. Engineering, Computer sciences

3. Math, Physics, Chemistry

4. Medicine

5. Others

5. Are you a member of the Chinese Communist Party?

1. Yes 2. NO

6. Did you ever participate in an experiment in economics before this one?

1. Yes 2. NO

7. Have you been a student cadre for a relatively long time?

1. Yes 2. NO

8. Suppose you face the following choice in reality, which one you would like to choose?

1. $0.1 \%$ chance of getting 100 thousand Yuan or getting 0 Yuan

2. $1 \%$ chance of getting 10 thousand Yuan or getting 0 Yuan

3. $10 \%$ chance of getting 1000 Yuan or getting 0 Yuan

4. $25 \%$ chance of getting 400 Yuan or getting 0 Yuan

$5.50 \%$ chance of getting 200 Yuan or getting 0 Yuan

$6.75 \%$ chance of getting 133 Yuan or getting 0 Yuan

7. $100 \%$ chance of getting 100 Yuan

9. Could you tell how much you trust people you meet for the first time, in general?

1. Trust completely

2. Trust a little

3. Neither trust or distrust

4. Not trust very much

5. Not trust at all

10. How much do you agree with the following statement: "I am trustworthy"?

1. Disagree strongly

2. Disagree somewhat

3. Disagree slightly

4. Agree slightly

5. Agree somewhat

6. Agree strongly

11. How much do you agree with the statement that you are good at finding whether a person is trustworthy?

1. Disagree strongly

2. Disagree somewhat

3. Disagree slightly 

4. Agree slightly
5. Agree somewhat
6. Agree strongly

12. How much do you agree with the following statement: "Generally, most people can be trusted"?
1. Disagree strongly
2. Disagree somewhat
3. Disagree slightly
4. Agree slightly
5. Agree somewhat
6. Agree strongly

14. How many public officials do you think accepted private transfers in the experiment on average?
1. All the officials
2. Most of the officials
3. About half of the officials
4. A small fraction of officials
5. No official

15. How widespread do you think bribing and corruption are in this country?
1. Almost all public officials are engaged in it
2. Most of them
3. About half of them
4. A small fraction of them
5. Almost no public officials are engaged in it

16. Please tell for the following statement whether you think it can always be justified, never be justified, or something in between, using a scale from 1 to 10 :

"Someone accepting a bribe in the course of his duties".

\section{Never justifiable \\ 10. Always justifiable}

17. Can you tolerate corruption? Please answer this question on a scale from 1 to 10 , where 10 means that you totally tolerate corruption and it is acceptable to you and 1 means that you never tolerate it.

1. I never tolerate corruption

10. I can fully tolerate corruption

18. Do you agree with the following statement? "Most people in this world cannot restrain themselves from the temptation of money. They sometimes may even do something against social morality for the sake of money."

1. Disagree strongly

2. Disagree somewhat

3. Disagree slightly

4. Agree slightly

5. Agree somewhat

6. Agree strongly

19. Suppose you are in a community of 100 members. The community is in a hank and faces the risk of breakup, which will cause every member lose 200 Yuan. Now you have 1000 Yuan. What is the maximum number you would like to donate to the community for going through difficulties?
1. 0
2. 100
3. 200
4. 300
5. 400
6. 500 

7. 600
8. 700
9. 800
10. 900
11. 1000

20. When you learn that doing a thing can have a negative consequence on others but can benefit you, would you still do it?
1. Yes
2. No

21. Are there other things that you would like to say about this experiment? 
Appendix 4. Independent variables: definition and descriptive statistics

Table A1. Independent variables and descriptive statistics

\begin{tabular}{|c|c|c|c|}
\hline Variables & Definition & Mean & $\begin{array}{l}\text { Std. } \\
\text { Dev. }\end{array}$ \\
\hline Male & Male $=1$, female $=0$ & 0.48 & 0.50 \\
\hline CCP member & $\begin{array}{l}\text { Member of the Chinese Communist Party, yes=1, } \\
\text { no }=0\end{array}$ & 0.26 & 0.44 \\
\hline Leadership & $\begin{array}{l}\text { Participants with long student leadership experience, } \\
\text { yes }=1, \text { no }=0\end{array}$ & 0.52 & 0.50 \\
\hline Distrust & $\begin{array}{l}\text { Question 9: Scale 1-5 with decreased trust on } \\
\text { strangers }\end{array}$ & 2.87 & 0.88 \\
\hline Belief_country & $\begin{array}{l}\text { Question 15: Belief on the corruption level in the } \\
\text { country, transformed into dummy, high corruption } \\
\text { belief }=1 \text {, if response is } 1 \text { or } 2,0 \text { otherwise }\end{array}$ & 0.58 & 0.50 \\
\hline Belief_exp & $\begin{array}{l}\text { Question 14: Belief on the corruption level in the } \\
\text { experiment, transformed into dummy, high corruption } \\
\text { belief }=1 \text { if response is } 1 \text { or } 2,0 \text { otherwise }\end{array}$ & 3.59 & 0.76 \\
\hline Justification & $\begin{array}{l}\text { Question 16: scale 1-10 with increased judgment on } \\
\text { the justifiability of corrupt behavior }\end{array}$ & 6.73 & 2.38 \\
\hline Help & $\begin{array}{l}\text { Question 19: scale } 0-10 \text { with increased willingness to } \\
\text { donate to a group to avoid losses for each member }\end{array}$ & 3.84 & 2.40 \\
\hline Risk propensity & $\begin{array}{l}\text { Lottery chosen in Part 1: 1-6 with increased risk } \\
\text { preference (1-4 risk aversion, } 5 \text { risk neutral, } 6 \text { risk } \\
\text { seeking) }\end{array}$ & 4.12 & 1.50 \\
\hline Sanction $_{t-1}$ & $\begin{array}{l}\text { Dummy for whether a collective sanction occurred in } \\
\text { the previous period, yes }=1, n o=0\end{array}$ & 0.26 & 0.44 \\
\hline Diff_bribe & $\begin{array}{l}\text { Amount of the bribe in the current period minus the } \\
\text { amount of the bribe offered in the previous period }\end{array}$ & 0.03 & 2.53 \\
\hline Permit $_{t-1}$ & $\begin{array}{l}\text { Dummy for whether permission was granted in the } \\
\text { previous period, yes }=1, \text { no }=0\end{array}$ & 0.46 & 0.50 \\
\hline
\end{tabular}

